\title{
Monogenic and chromosomal causes of isolated speech and language impairment
}

\author{
C P Barnett, ${ }^{1}$ B W M van Bon ${ }^{1,2}$
}

\begin{abstract}
- Additional material is published online only. To view please visit the journal online (http://dx.doi.org/10.1136/ jmedgenet-2015-103161)

${ }^{1}$ Paediatric \& Reproductive Genetics, SA Clinical Genetics Service, Women's and Children's Hospital/SA Pathology, North Adelaide, South Australia, Australia ${ }^{2}$ Department of Human Genetics, Radboud Institute for molecular Life Sciences, Radboud University Medical Center, Nijmegen,

The Netherlands
\end{abstract}

\section{Correspondence to} Dr B W M van Bon, Department of Human Genetics, Radboud Institute for molecular Life Sciences, Radboud University Medical Center, PO Box 9101, 6500 HB Nijmegen, The Netherlands; Bregje.vanbon@radboudumc.nl

Received 13 April 2015 Revised 10 June 2015 Accepted 11 June 2015 Published Online First 2 July 2015

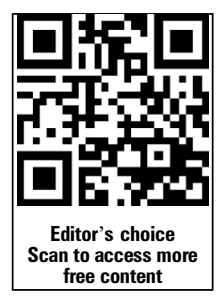

CrossMark

To cite: Barnett $C P$, van Bon BWM. J Med Genet 2015;52:719-729.

\section{ABSTRACT}

The importance of a precise molecular diagnosis for children with intellectual disability, autism spectrum disorder and epilepsy has become widely accepted and genetic testing is an integral part of the diagnostic evaluation of these children. In contrast, children with an isolated speech or language disorder are not often genetically evaluated, despite recent evidence supporting a role for genetic factors in the aetiology of these disorders. Several chromosomal copy number variants and single gene disorders associated with abnormalities of speech and language have been identified. Individuals without a precise genetic diagnosis will not receive optimal management including interventions such as early testosterone replacement in Klinefelter syndrome, otorhinolaryngological and audiometric evaluation in 22q11.2 deletion syndrome, cardiovascular surveillance in 7q11.23 duplications and early dietary management to prevent obesity in proximal 16p11.2 deletions. This review summarises the clinical features, aetiology and management options of known chromosomal and single gene disorders that are associated with speech and language pathology in the setting of normal or only mildly impaired cognitive function.

\section{INTRODUCTION}

Over the last decade, molecular genetic testing of children with moderate to severe intellectual disability (ID), autism spectrum disorder (ASD) and epilepsy has become an integral part of the diagnostic evaluation of these children. The importance of a precise molecular diagnosis in informing the clinician about optimal management, prognosis and genetic counselling is widely accepted. ${ }^{1}$ Speech and language abnormalities frequently co-occur with these developmental disorders and as a result, clinical geneticists are frequently asked to assess children with speech and language difficulties. Severe language delay is also a symptom of several well recognised genetic conditions presenting to clinical geneticists such as Pitt-Hopkins syndrome and Angelman syndrome (AS). ${ }^{2}{ }^{3}$ In contrast, children with an isolated speech or language disorder are not often genetically evaluated, despite recent evidence supporting a role for genetic factors in the aetiology of these disorders. ${ }^{4-9}$

Several types of speech and language pathology have been described although nomenclature is somewhat variable (for a summary of useful definitions see online supplementary appendix). ${ }^{10} 11$ In general, speech disorders include voice problems and/or the inability to produce speech sounds correctly or fluently. Language disorders include expressive and receptive language disorders. Children with an expressive language disorder are more able to understand language than they are to express themselves with language. Such children also frequently have receptive language delay; difficulties understanding language. Expressive and receptive language delay can occur separately or together in an individual and either can be isolated or occur as part of a broader developmental problem.

During the past few years, advances in genetic technology have led to the identification of several chromosomal CNVs and single gene changes associated with abnormalities of speech and language. A major drawback of many of these reports is the lack of a standardised description of the type of speech/language disorder reported. As a consequence, the potential relevance of these reported genetic alterations to the causation of speech/language disorders is often not highlighted in the literature. Furthermore, in contrast to genetic syndromes, disorders of speech/language may be overlooked as they often present without clearly defined clinical features. This is particularly true when speech or language problems are the main presenting symptom in a child who has only mild developmental delay or otherwise normal development. Individuals without a precise genetic diagnosis are less likely to receive optimal management including beneficial treatment interventions. This review summarises the clinical features, aetiology and management options of known chromosomal (table 1) and single gene disorders (table 2) that are associated with speech and language pathology which can occur in the setting of normal or only mildly impaired cognitive function.

\section{METHODS \\ Selection criteria}

This review aims to report on monogenic and chromosomal disorders involving speech and language pathology. Information on chromosome and single gene disorders associated with developmental speech and language problems was extracted from PubMed using search terms 'speech', 'language', 'chromosome' and 'mutation'. Genome wide association studies were excluded from this review. In addition, to prevent bias towards specific types of speech and language pathology we did not extend the search to terms indicating (sub)types or symptoms of speech and language pathology (eg, search terms such as dysarthria, apraxia, stuttering, phonation deficits were not used).

In addition, this report aimed to focus on primary speech and language pathology, which we define as speech and language pathology occurring in the setting of normal or only mildly impaired cognitive function. The reason for this focus is that historically genetic testing has often not been 
Table 1 Chromosomal aberrations that are associated with speech and language pathology and can occur in the setting of normal or only mildly impaired cognitive function

\begin{tabular}{|c|c|c|c|c|}
\hline $\begin{array}{l}\text { Chromosome disorder } \\
\text { (name syndrome) }\end{array}$ & $\begin{array}{l}\text { Chromosome position (Hg19) } \\
\text { and major candidate genes } \\
\text { phenotype }\end{array}$ & Clinical features & $\begin{array}{l}\text { No. of } \\
\text { publ. } \\
\text { cases }\end{array}$ & $\begin{array}{l}\text { Considerations for medical } \\
\text { follow-up* }\end{array}$ \\
\hline 1p21.3 microdeletion & $\begin{array}{l}\text { Chr 1: } 97.5-98.5 \mathrm{Mb} \\
\text { DPYD and MIR137 }\end{array}$ & Normal IQ-mild ID, severe speech delay, ASD & $<20$ & $\begin{array}{l}\text { Counselling carrier status } \\
\text { dihydropyrimidine dehydrogenase } \\
\text { deficiency }\end{array}$ \\
\hline $\begin{array}{l}\text { 7q11.23 microduplication } \\
\text { (OMIM 609757) }\end{array}$ & $\begin{array}{l}\text { Chr 7: } 72.8-74.3 \mathrm{Mb} \\
\text { GTF2I }\end{array}$ & $\begin{array}{l}\text { Normal IQ-moderate ID, dysmorphia, hypotonia, severe } \\
\text { expressive language delay, dysarthria, aortopathy }\end{array}$ & $>75$ & Cardiac evaluation \\
\hline 10q22q23 microdeletion & Chr10: 81.6-89.1 Mb & $\begin{array}{l}\text { Borderline-moderate ID, expressive/ receptive language } \\
\text { delay, macrocephaly, dysmorphia, cardiac anomalies, } \\
\text { cerebellar anomalies }\end{array}$ & $<20$ & $\begin{array}{l}\text { Cardiac evaluation and } \mathrm{Gl} \\
\text { follow-up }\end{array}$ \\
\hline $\begin{array}{l}\text { 12p12.1 microdeletion } \\
\text { (OMIM 604975) }\end{array}$ & $\begin{array}{l}\text { Chr 12: 23.7-24.7 Mb } \\
\text { SOX5 }\end{array}$ & $\begin{array}{l}\text { Normal IQ-moderate ID, expressive language delay, } \\
\text { mutism, ADHD, aggression }\end{array}$ & $<20$ & - \\
\hline 12p13.33 microdeletion & $\begin{array}{l}\text { Chr12: 1.1-1.6 Mb } \\
\text { ELKS/ERC1 }\end{array}$ & Normal IQ-mild ID CAS, ADHD, DD & $<20$ & - \\
\hline $\begin{array}{l}\text { 15q11.2 microdeletion } \\
\text { (OMIM 615656) }\end{array}$ & $\begin{array}{l}\text { Chr15: } 22.8-23.1 \mathrm{Mb} \\
\text { NIPA1, NIPA2, CYFIP1 and } \\
\text { TUBGCP5 }\end{array}$ & $\begin{array}{l}\text { Normal IQ-mild ID Speech and language delay, ADHD, } \\
\text { ASD, epilepsy, CHD }\end{array}$ & $>100$ & Cardiac evaluation \\
\hline $\begin{array}{l}15 q 11.2 q 13 \\
\text { microduplication } \\
\text { (OMIM 608636) }\end{array}$ & Chr15: 23.1-28.9 Mb & $\begin{array}{l}\text { Normal IQ-moderate ID, parent of origin effect, speech } \\
\text { delay, apraxia, dyslexia, motor delay, hypotonia, ASD }\end{array}$ & $>75$ & $\begin{array}{l}\text { Awareness and treatment of } \mathrm{Gl} \\
\text { symptoms }\end{array}$ \\
\hline $\begin{array}{l}\text { Proximal } 16 p 11.2 \\
\text { microdeletion } \\
\text { (OMIM 611913) }\end{array}$ & Chr16: 29.5-30.3 Mb & $\begin{array}{l}\text { Normal IQ-moderate ID, speech/language delay, } \\
\text { obesity, CAS, congenital abnormalities }\end{array}$ & $>75$ & Dietary management \\
\hline $\begin{array}{l}\text { 17p11.2p11.2 } \\
\text { microduplication } \\
\text { (Potocki-Lupski } \\
\text { syndrome) } \\
\text { (OMIM 610883) }\end{array}$ & Chr 17: 16.8-20.3 Mb & $\begin{array}{l}\text { Low-average IQ-moderate ID, speech/language delay, } \\
\text { ASD, hypotonia, feeding difficulties, behavioural } \\
\text { problems, CHD, aortopathy }\end{array}$ & $>75$ & $\begin{array}{l}\text { Cardiac evaluation, assessment of } \\
\text { sleep apnoea }\end{array}$ \\
\hline $\begin{array}{l}22 q 11.2 \text { microdeletion } \\
\text { (velocardiofacial } \\
\text { syndrome) } \\
\text { (OMIM 192430) }\end{array}$ & $\begin{array}{l}\text { Chr } 22: 18.7-21.8 \mathrm{Mb} \\
T B X 1 \text { and COMT }\end{array}$ & $\begin{array}{l}\text { Normal IQ-mild ID, speech/language delay, CHD, } \\
\text { velopharyngeal insufficiency, cleft palate, hypotonia }\end{array}$ & $>100$ & $\begin{array}{l}\text { Multiple medical } \\
\text { recommendations: see published } \\
\text { guidelines }{ }^{12-14}\end{array}$ \\
\hline $\begin{array}{l}22 q 11.2 \text { distal } \\
\text { microdeletion } \\
\text { (OMIM 611867) }\end{array}$ & Chr22: 22.1-23.8 Mb & $\begin{array}{l}\text { Normal IQ-mild ID, hearing loss, speech/language } \\
\text { delay, gross delay, behavioural problems, CHD }\end{array}$ & $>25$ & $\begin{array}{l}\text { Hearing assessment, cardiac } \\
\text { evaluation }\end{array}$ \\
\hline $\begin{array}{l}\text { Sex chromosome } \\
\text { aneuploidy }\end{array}$ & $\begin{array}{l}47, X X Y \\
47, X Y Y \\
47, X X X \\
45, X \dagger\end{array}$ & $\begin{array}{l}\text { Average IQ/mild DD, ADHD, features of hypogonadism } \\
\text { Average IQ/mild } D D, A D H D \\
\text { Average IQ, mild DD, ADHD } \\
\text { Average IQ, features of ovarian dysgenesis }\end{array}$ & $\begin{array}{l}>100 \\
>100 \\
>100 \\
>100\end{array}$ & $\begin{array}{l}\text { Multiple medical } \\
\text { recommendations: see published } \\
\text { guidelines }^{15} \\
\text { - } \\
\text { - } \\
\text { See published guidelines }^{16}\end{array}$ \\
\hline
\end{tabular}

${ }^{*}$ Medical surveillance to consider in addition to speech/language evaluation and therapy.

tIn general, individuals with Turner syndrome have average to above average performance on most verbal tasks, however there is evidence that oral fluency skills are impaired. ADHD, attention-deficit hyperactivity disorder; ASD, autism spectrum disorder; CAS, childhood apraxia of speech; CHD, congenital heart disease; DD, developmental delay; GI, gastrointestinal; ID, intellectual disability; No., number; publ, published.

performed in these individuals because of the lack of clear comorbidities such as cognitive impairment, dysmorphism or congenital anomalies. Disorders have only been selected under the condition that normal or borderline intellectual function has been reported as part of the cognitive spectrum. Disorders lacking literature descriptions of individuals with normal/borderline cognitive function were excluded from this review.

\section{Chromosomal disorders}

CNVs include deletions and duplications on chromosomes and are a common type of genomic variation. Copy number changes may range in size from a kilobase $(\mathrm{kb})$ to several megabases $(\mathrm{Mb})$ or even a whole chromosome (trisomies and monosomies) and may comprise one or more genes. ${ }^{1} \mathrm{CNV}$ s can be detected using genomic microarrays, which are often used as a first-tier test in the evaluation of individuals with developmental delay, autism, epilepsy and/or congenital anomalies. Clinical interpretation of rare $\mathrm{CNV}$ s still remains challenging as many $\mathrm{CNV}$ are rare and non-recurrent and large cohort studies of healthy control individuals have shown that each person carries multiple, most often benign, CNVs. ${ }^{1}$ In general, interpretation of the causality of a CNV in an affected individual is based on its frequency in healthy control individuals, the inheritance pattern in the respective family, the presence of overlapping aberrations in patients with similar phenotypes and the CNV characteristics such as size, copy number state (gain or loss) and gene content. ${ }^{17}$ Nevertheless, rare CNVs that are inherited from healthy parents may remain difficult to interpret as variable expressivity and decreased penetrance may occur. ${ }^{17}$ The CNVs included in this review have all been reported as pathogenic, yet penetrance and expressivity may still be variable for each of these disorders. Smaller CNVs located within or only partly overlapping these genomic regions may still be of a benign nature. A CNV may result in disruption of gene structure or change in gene dosage. Where known, information on candidate genes underlying the phenotypical features is discussed. 
Table 2 Single gene disorders that are associated with speech and language pathology and can occur in the setting of normal or only mildly impaired cognitive function

\begin{tabular}{|c|c|c|c|c|}
\hline Gene (name disorder) & $\begin{array}{l}\text { Chromosome position } \\
\text { (Hg19) }\end{array}$ & Clinical features & $\begin{array}{l}\text { No. of } \\
\text { publ. cases }\end{array}$ & Considerations for medical follow-up* \\
\hline $\begin{array}{l}\text { FOXP2 (OMIM 602081) } \\
\text { (Speech and language } \\
\text { disorder 1) }\end{array}$ & Chr 7: 113.7-114.3 Mb & $\begin{array}{l}\text { Normal IQ-mild DD, severe speech delay, verbal } \\
\text { dyspraxia }\end{array}$ & $>25$ & - \\
\hline $\begin{array}{l}\text { SETBP1 (OMIM } \\
611060)\end{array}$ & Chr 18: 42.3-42.6 Mb & Normal IQ-severe ID mutism, severe speech delay & $<10$ & - \\
\hline $\begin{array}{l}\text { TM4SF20 (OMIM } \\
615432)\end{array}$ & Chr 2: 228.2-228.2 Mb & $\begin{array}{l}\text { Normal IQ, speech delay, white matter } \\
\text { hyperintensities }\end{array}$ & 15 families & - \\
\hline $\begin{array}{l}\text { FMR1 (OMIM 309550) } \\
\text { (Fragile X syndrome in } \\
\text { women) }\end{array}$ & Chr X: 147.0-147.0 Mb & $\begin{array}{l}\text { Normal IQ-moderate ID, speech delay, POI and } \\
\text { FXTAS }\end{array}$ & $>100$ & $\begin{array}{l}\text { Reproductive endocrine evaluation and } \\
\text { treatment supportive care for gait } \\
\text { disturbances }\end{array}$ \\
\hline $\begin{array}{l}\text { GALT (OMIM 606999) } \\
\text { (Treated classic } \\
\text { galactosaemia) }\end{array}$ & Chr 9: 34.6-34.7 Mb & $\begin{array}{l}\text { Normal IQ-borderline ID, vocabulary and articulation } \\
\text { problems, CAS and dysarthria, motor disturbances, } \\
\text { POI }\end{array}$ & $>100$ & $\begin{array}{l}\text { Galactosaemia treatment from birth onwards } \\
\text { Reproductive endocrine evaluation and } \\
\text { treatment }\end{array}$ \\
\hline NRXN1 (OMIM 600565) & Chr 2: $50.1-51.3 \mathrm{Mb}$ & $\begin{array}{l}\text { Normal IQ-DD, ASD, speech and language delay, } \\
\text { CHD, epilepsy }\end{array}$ & $>75$ & Cardiac evaluation \\
\hline $\begin{array}{l}\text { GRIN2A (OMIM } \\
\text { 138253) } \\
\text { (Landau-Kleffner } \\
\text { syndrome) }\end{array}$ & Chr 16: 9.8-10.3 Mb & $\begin{array}{l}\text { Normal IQ-mild ID, dyspraxia, impaired motor } \\
\text { planning and programming and dysarthria, epilepsy }\end{array}$ & $>50$ & Epilepsy monitoring and treatment \\
\hline
\end{tabular}

\section{1p21.3 deletion}

Less than 10 individuals with a deletion of chromosome $1 \mathrm{p} 21.3$ including DPYD and MIR137 have been reported. ${ }^{18} 19$ They showed severe speech delay, features of ASD, normal gross motor development and absence of major medical problems. Cognitive function varied between IQ in the normal range and borderline-mild ID. Several individuals showed a discrepancy between verbal and performance IQ with a relatively low score on verbal capacities. Speech deficits included poor intelligibility and pronunciation difficulties. There is at least one report of an intragenic deletion in DPYD in a patient with speech delay and autism, suggesting that DPYD is a candidate gene for speech delay. ${ }^{18}$ Point mutations and intragenic deletions in DPYD confer carrier status for dihydropyrimidine dehydrogenase deficiency. Recently, a rare variant in MIR137 has been reported as a possible risk factor in schizophrenia and bipolar disorder. ${ }^{20}$

\section{7q11.23 microduplication}

Williams-Beuren syndrome (WBS) is a recognisable microdeletion syndrome, caused by a $1.5 \mathrm{Mb}$ deletion at $7 \mathrm{q} 11.23 .{ }^{21} 22$ WBS is characterised by a typical facial gestalt, supravalvular aortic stenosis, infantile hypercalcaemia and a specific cognitive profile. The reciprocal duplication was first reported in $2005 .^{8}$ This boy showed mild developmental delay, severe expressive language impairment, hypotonia and mild dysmorphic features. These features have subsequently been confirmed as common features of this duplication in large cohorts. ${ }^{23} 24$ In contrast to WBS, characterised by fluent expressive language, duplication carriers show impaired expressive language characterised by oral motor problems and speech sound delays and disorders. ${ }^{25}$ Children have been reported with mixed motor speech disorders including childhood apraxia of speech (CAS), dysarthria, phonological disorder and/or oral apraxia. ${ }^{25}$ Although the majority of carrier adults also showed symptoms of these disorders, none of them showed enough symptoms to meet the criteria to be diagnosed with a speech disorder. ${ }^{25}$ The intellectual abilities of children with this microduplication varied from mild- moderate ID to average for the general population. ${ }^{25}$ Most duplication carrier parents showed a history of learning difficulties and/or language delay but were employed and functioning well in adult life. ${ }^{23} 24$ Due to the finding of cardiac defects and aortopathy in a subset of individuals, cardiovascular surveillance has been recommended for these patients. ${ }^{26}$ Minor dysmorphic features, neonatal hypotonia, various brain anomalies, cleft palate, epilepsy, cryptorchidism, joint laxity, attention-deficit hyperactivity disorder (ADHD) and autistic features have also been reported in some individuals. ${ }^{23} 27$ One study reported separation-anxiety disorder in $30 \%$ of $4-12$-year-old individuals with a duplication. The GTF2I gene has been suggested as the most important gene contributing to the cognitive phenotype in WBS. $^{28}$ An extra copy of Gtf $2 i$ in mice leads to increased separation-induced anxiety in these animals, suggesting an important role of GTF2I in this phenotype. ${ }^{29}$

\section{Deletions of chromosome 10q22q23}

Deletions of chromosome 10q22q23, between two low copy repeats (LCR3 and LCR4), lead to borderline-moderate cognitive impairment with apparent speech and language problems. $^{30-32}$ Motor developmental delay may also occur, although speech seems more severely affected. The majority has expressive and receptive language problems. In addition, auditory language processing, speech impairment and mild oral motor deficits have been reported. Macrocephaly, mild facial dysmorphisms (broad forehead, deep-set eyes, upslanting palpebral fissures, a smooth philtrum and a thin upper lip), cerebellar anomalies, cardiac defects and congenital breast aplasia have been described. ${ }^{30}$ Parental inheritance with segregation of the phenotype has been reported. ${ }^{31}$ Cardiac evaluation in newly diagnosed individuals is recommended as cardiac anomalies such as persisting ductus arteriosis, atrioventricular septal defects and tricuspid and pulmonic regurgitation have been reported. Mutations and exonic deletions in BMPR1A are associated with juvenile polyposis syndrome (JPS). ${ }^{33}$ So far, no polyps have been reported in LCR3-LCR4 10q22q23 deletion 
carriers. However, the majority of carriers have been described before the age of 12 years. Symptoms of JPS, such as rectal bleeding, usually present in older children and young adults. Colorectal cancer as a result of transformation of these polyps usually does not occur until the fourth decade and does not occur in all individuals with JPS. ${ }^{34}$ Therefore, appropriate gastrointestinal (GI) follow-up from 15 years onwards may be considered. $^{32}$

\section{Deletions of 12p12.1}

Deletions of $12 \mathrm{p} 12.1$ including the translated region of SOX5 are associated with developmental delay with prominent language delay without specific associated physical abnormalities. $^{35-37}$ Average intellectual development has been reported in a patient with an atypical deletion limited to the untranslated region of SOX5, but most individuals show borderline, mild or moderate intellectual impairment. All individuals with alterations of SOX5 have been reported with a predominantly expressive language disorder. Complete absence of language has occasionally been reported. Other features included poor articulation and dyspraxia. Behaviour problems included aggressive behaviour, self-injurious behaviour and ADHD. ${ }^{37}$

\section{Deletions of $12 \mathrm{p} 13.33$}

In most carriers of a $12 \mathrm{p} 13.3$ deletion the first symptom was speech delay, with first words at around 36-40 months. ${ }^{38}$ In some, walking development was also delayed. All individuals who were available for professional assessment by a speech pathologist could be diagnosed with CAS. Deletions were inherited from a parent in around half of the cases. Variable expression within families has been reported. The majority showed borderline-mild ID. Some individuals had a normal IQ. However, retrospective interviews revealed all had speech delay and learning difficulties during childhood and none of them graduated secondary school. ADHD and behaviour problems have been frequently reported. The ELKS/ERC1 gene has been proposed as the best candidate gene as it is the only gene located in the smallest region of overlap in all individuals with $12 \mathrm{p} 13.33$ deletions and speech delay. ${ }^{38}$

\section{Deletions of $15 q 11.2$}

The proximal $15 \mathrm{q}$ region is characterised by a high density of segmentally duplicated blocks. ${ }^{39} 40$ Speech and language and motor developmental delay are common in individuals with deletions of chromosome $15 \mathrm{q} 11.2$ between the first pair of segmentally duplicated blocks adjacent to the Prader-Willi syndrome and AS critical region. ${ }^{41-43}$ The possible involvement of this region in speech impairment has also been shown in a study reporting an increased absence of vocalisation in AS individuals that carry the larger deletion including this proximal region. ${ }^{44}$ The $500 \mathrm{~kb}$ region includes four non-imprinted genes, NIPA1, NIPA2, CYFIP1 and TUBGCP5. Three of these genes are implicated in central nervous system development and/or function. $^{42} 45$ Most individuals show normal development or only mild cognitive impairment. ${ }^{41}$ Speech delay has been reported in the majority of individuals although formal speech and language assessment studies would be useful to further specify these findings. ${ }^{41-43}$ Behaviour issues including ADHD or ASD, epilepsy and congenital heart disease have also been reported in a subset of individuals. ${ }^{43} 46$ The latter may be underestimated as most individuals do not come to the attention of a physician due to the mild phenotype. Therefore echocardiographic examination has been recommended for these individuals. ${ }^{43}$
$15 q 11.2 q 13$ microduplication

Similar to the reciprocal 15q11.2q13 deletion in Prader-Willi syndrome and AS there are two types of aberrations. Type I duplications occur between segmentally duplicated blocks BP1 and BP3 and type II duplications between BP2 and BP3. ${ }^{47}$ Despite the uniformity of the duplication sizes, the phenotype may be highly variable, even within the same family. ${ }^{48}$ Paternal origin of the duplication is usually associated with a normal or mild phenotype. ${ }^{49}$ The level of intellectual functioning varies from normal development to marked cognitive impairment. ${ }^{50-52}$ Speech delay is reported in the majority of individuals. In one family with multiple affected individuals formal language assessment revealed apraxia of speech, phonological awareness deficits, developmental language disorder, dyslexia and limb apraxia. ${ }^{48}$ In another study receptive language difficulties were reported. ${ }^{50}$ Additional frequently reported features include motor delay, hypotonia, joint laxity, autism and GI problems. ${ }^{51-53}$ The latter include reflux and constipation in the majority of cases. ${ }^{53}$ Behaviour problems, possibly caused by GI related discomfort, have been reported to improve with treatment of GI symptoms in several individuals. However, GI problems may be difficult to diagnose in individuals with severe speech and language difficulties warranting increased awareness for early diagnosis and treatment. Most common treatments were stool softeners and stimulants such as polyethylene glycol and bisacodyl for constipation and proton pump inhibitors for reflux. In most cases, major dysmorphisms or congenital anomalies are absent. ${ }^{51} 52$

\section{Proximal 16p11.2 microdeletion}

Recurrent proximal deletions at $16 \mathrm{p} 11.2$ have been associated with intellectual impairment, speech and language delays, autism and obesity. ${ }^{54-56}$ Early diagnosis and dietary management may help to prevent excessive weight gain/obesity. ${ }^{57}$ The frequency of this deletion may exceed 1:5000 and is found in approximately $0.5 \%$ of all samples tested clinically. ${ }^{55}$ The role of this genomic region in speech/language development has been confirmed by several studies. In one study ( $n=9$ individuals) reporting on developmental milestones for speech-language acquisition $67 \%$ had significant delays in age of single word acquisition, $78 \%$ had delays in age of phrase development and all had deficits in reciprocal conversation. ${ }^{59}$ Recently, carriers of a $16 \mathrm{p} 11.2$ deletion with CAS have been reported. ${ }^{59} 60$ Three studies on large cohorts of carriers and intrafamilial non-carrier controls showed that relative to family members without the deletion carriers showed a 1.7-2 SD decrease in IQ. ${ }^{61-63}$ Among carriers of one of these studies, 20\% met Diagnostic and Statistical Manual VText Revision (DSM V-TR) criteria for ID (65\% mild and 35\% moderate). ${ }^{61}$ A consistent deficit in expressive and receptive spoken language and articulation could be observed. ${ }^{61}$ Verbal IQ (mean 74) was lower than non-verbal IQ (mean 83) and the majority of carriers required speech therapy. ${ }^{62}$ ASD could be diagnosed in $15-24 \%$ of all individuals. ${ }^{61}{ }^{62}$ In addition, other psychiatric disorders or autism-related traits were noted in the majority of individuals. A recent study showed that despite large deleterious effects, there is a significant positive correlation between the full-scale IQ, verbal IQ and social responsiveness scale between parents and probands with a de novo deletion. These results indicate that family background has a strong contribution to the phenotypical variability of this genomic disorder.

Recently, an adjacent non-overlapping 16p11.2 deletion involving the SRCAP gene was described in a girl with severe speech impairment and behaviour problems. Her IQ was tested in the normal range. ${ }^{64}$ No additional individuals with similar 
deletions have been reported yet, and therefore this deletion has not been included as a separate disorder.

\section{7p11.2 duplication}

Potocki-Lupski syndrome is caused by duplication of chromosome $17 \mathrm{p} 11.2$ and is the reciprocal product of the Smith-Magenis syndrome microdeletion. Except for a minority with low-average to borderline intellectual function, most individuals show intellectual impairment in the mild-moderate range. Other features include significant speech and language delay, autism, hypotonia, prominent sucking/feeding difficulties, behaviour problems, sleep apnoea and cardiovascular anomalies such as structural heart disease, aortopathy and ECG anomalies. ${ }^{65-68}$ Therefore individuals with Potocki-Lupski syndrome should be evaluated and monitored by ECG and echocardiography. ${ }^{68}$ In addition, assessment of sleep-disordered breathing may be considered. ${ }^{66}$ Most cases are sporadic, but familial transmission has been observed in a few families. ${ }^{69} 70$ Speech and language impairment is a consistent finding, regardless of the level of cognitive and social functioning. A better non-verbal function compared with verbal function, apraxia of speech and expressive and receptive language difficulties have been observed. ${ }^{6671} \mathrm{~A}$ small study reported echolalia, intonation and rhythm abnormalities, the usage of pedantic language, running commentaries and reference to themselves in the third person. ${ }^{67}$

\section{2q11.2 microdeletion syndrome}

Different classifications, such as velocardiofacial syndrome, Shprintzen syndrome and DiGeorge syndrome, are all presentations of 22q11.2 deletion. ${ }^{72}$ Common features include mild developmental delay (mean IQ in the low 70s, 30\% between 80 and 100), speech and language problems, velopharyngeal insufficiency, cleft palate, hypotonia, constipation, conotruncal cardiac malformations and thymus and parathyroid hypoplasia. In addition, patients may have seizures, abnormal hearing, urogenital anomalies, psychiatric illness, behavioural problems and dysmorphisms. ${ }^{12}{ }^{73-75}$ Clinical guidelines for evaluation and therapeutic management of children and adults with 22q11.2 deletion syndrome are useful to tailor clinical care during different stages of life. ${ }^{12-14}$ The estimated frequency varies from $1: 4000$ to $1: 6395 .^{76} 77$ In $8-28 \%$ of cases the deletion is inherited from a parent. ${ }^{7478} 79$ Speech and language delay has been observed in $70 \%$ of individuals during follow-up. ${ }^{80}$ Significant discrepancy between receptive and expressive language has been reported. ${ }^{7}$ Phonation defects due to velopharyngeal insufficiency and hearing difficulties influence language acquisition in many patients. ${ }^{80}$ Therefore, otorhinolaryngological and early audiometric evaluation has been recommended. ${ }^{80}$ Deviant articulation and reduced intelligibility has been reported to improve significantly with age. ${ }^{81}$ However, persistent problems with velopharyngeal impairment have been noted. ${ }^{81} T B X 1$ and COMT have been suggested as candidate genes for the neurocognitive and anatomical abnormalities that lead to speech disturbance in 22q11.2 microdeletion syndrome. ${ }^{82}$

\section{2q11.2 distal microdeletion}

Distal 22q11.2 deletions, located between segmental duplication blocks LCR22-4 to LCR22-5 or LCR22-6, represent a different clinical phenotype compared with more proximal deletions associated with the well known DiGeorge/velocardiofacial phenotypes. ${ }^{83-86}$ Most deletions occur de novo, but inheritance has also been reported. ${ }^{87} 88$ Cognitive function in individuals with this deletion varies from normal to mild cognitive impairment with a significant language delay component. ${ }^{87}{ }^{88}$ Several patients with hearing impairment have been reported, warranting evaluation to optimise conditions for development. ${ }^{87}$ Except for single case descriptions of affected speech and language, further studies are needed to increase insight in the associated speech and language pathology. Commonly noted other features include prematurity, growth retardation, behavioural problems, truncus arteriosus, variable minor skeletal abnormalities and subtle facial dysmorphisms. ${ }^{83} 8487$ Larger deletions, also including the region between LCR22-6 and LCR22-7 harbouring the INI1 (SMARCB1) gene, have been associated with an elevated risk of developing rhabdoid tumours. ${ }^{89}$

\section{Sex chromosome aneuploidies}

The sex chromosome trisomies include Klinefelter syndrome (47,XXY; 1.72:1000 men), XYY syndrome (47,XYY; 1:1000 men) and triple $\mathrm{X}$ syndrome $\left(47, \mathrm{XXX} ; 1: 1000\right.$ women).$^{90}$ Although most adults with sex chromosome trisomies live independent lives, they have been associated with significant language and reading problems. ${ }^{5} 991$ A poor verbal ability and behavioural and social difficulties have been reported. ${ }^{91}$ In a recent study, which investigated the prevalence of sex chromosome aneuploidies within a group of children and young adults with language and reading problems, aneuploidies were found in $2.9-3.4 \%$ of probands with oral speech and language deficits compared with an expected population frequency of $0.25 \%{ }^{9}$ Due to decreased awareness among health professionals Klinefelter syndrome remains undiagnosed in up to $75 \%$ of individuals. ${ }^{15}$ Early detection of this syndrome is important to offer appropriate management at the correct ages and stages of development to decrease potential learning and psychosocial problems, to prevent osteopenia and osteoporosis, metabolic syndrome and other medical conditions related to hypogonadism. ${ }^{15}$ These now include evidence that early (age 15-17 years) sperm retrieval in men with Klinefelter syndrome can result in successful pregnancy via in vitro fertilisation in the future. ${ }^{92}$ Guidelines summarising the clinical features and the various options for treatment and intervention are available to diagnose this syndrome as early as possible and to optimise care for these individuals. ${ }^{15}$ Klinefelter syndrome presents with global delays in speech from early development and up to $80 \%$ of individuals present with, mainly language related, learning disabilities during childhood. ${ }^{93}$ Most severe deficits include encoding of verbal information, auditory processing, comprehensions and processing speed. Expressive speech and verbal fluency are also affected. Overall intellectual function is in the average to lowaverage range. Nearly $50 \%$ of individuals has also been diagnosed with ADHD. ${ }^{93}$

Verbal impairments in XYY syndrome are comparable to Klinefelter syndrome. ${ }^{93}$ They consist of difficulty in naming, receptive vocabulary and verbal fluency. Intelligence is within the normal or slightly low-average range. ${ }^{93}$ Increased impulsivity and externalising behaviours have been reported and ADHD is diagnosed in up to $62 \%$ of cases. ${ }^{93}$

In women with triple $\mathrm{X}$ syndrome expressive language is more impaired compared with receptive language with a pattern described as developmental dyspraxia in some individuals. ${ }^{93} 94$ However, impairments in expressive and receptive language have also been reported. ${ }^{94}$ Language difficulties include language processing, verbal fluency, language comprehension and pragmatic language difficulties. ${ }^{94}$ Average full scale IQ is between 85 and 90 with a difference between verbal and nonverbal/performance domains with main deficits in verbal function. ${ }^{94}$ ADHD is present in $25-35 \%$ of cases. ${ }^{94}$ 
In contrast to the aforementioned sex chromosome aneuploidies, studies regarding speech and language abilities in Turner syndrome are harder to interpret. ${ }^{95}$ Group data support the general view of normal to strong verbal abilities in these individuals. ${ }^{16}$ However, this language strength seems not global, there is evidence that oral fluency skills are impaired despite average to above average performance on most other verbal tasks. ${ }^{96} 97$ In addition, a retrospective study under 54 parents of individuals with Turner syndrome reported late speech and language development in 22 children. ${ }^{98}$ Partially, this relatively high percentage may have been caused by recurrent otitis during infancy, which is a common feature of Turner syndrome. Turner syndrome occurs with an incidence of about 1/2500 women. ${ }^{99}$ Average IQ is between 95 and 102. ${ }^{95}$ The main features include short stature and ovarian dysgenesis. Other visceral manifestations may include lymphoedema, deafness, cardiovascular thyroid and GI involvement. ${ }^{16}$ Guidelines for diagnosis and optimal management including growth hormone treatment are available. $^{16}$

\section{Single gene disorders FOXP2}

FOXP2 (Forkhead box protein P2) was the first gene associated with severe speech disorder. Mutations and gene deletions of FOXP2 lead to developmental verbal dyspraxia with impaired expressive and receptive language. ${ }^{100-102}$ Some individuals also show mild developmental delay. FOXP2 was first discovered in a large three generational pedigree with multiple affected family members. Using linkage studies, a region on chromosome 7q31 was found to be segregating with the disorder. ${ }^{103} \mathrm{~A}$ de novo balanced translocation in an unrelated child with similar speech problems subsequently pinpointed to the causative gene. ${ }^{100} 104$ Prevalence of mutations in individuals with severe speech disorders has been estimated at $2 \% .{ }^{105}$

The core phenotype consists of a severe motor speech disorder, with most individuals having CAS. Oral motor dyspraxia, unintelligible speech, dysarthria, impaired word reading, spelling and phonological awareness skills have also been reported $^{102} 106107$ Receptive and expressive language is usually affected. Non-verbal performance within the normal range has been reported in some individuals and is often better compared with verbal skills. ${ }^{102} 106107$

Functional cooperativity has been demonstrated for Foxp1 and Foxp2 in mouse development and an overlap in expression in the songbird and human fetal brain has suggested that FOXP1 may also have a role in speech and language disorders. $^{108} 109$ Deletion or inactivating mutations of FOXP1 are indeed also associated with moderate to severe speech and language delay. ${ }^{110-112}$ In these individuals expressive language is more severely affected compared with receptive skills and they may show difficulties with articulation of consonants. ${ }^{110-112}$ However, the majority of individuals thus far reported also show moderate ID and therefore this gene is not included as single gene disorder in table 2. Other features include facial dysmorphisms, relative macrocephaly and autistic traits. ${ }^{110-112}$

\section{SETBP1}

Haploinsufficiency of SETBP1 has been postulated as the causative gene for expressive speech delay in individuals with chromosome $18 \mathrm{q} 12.3$ deletions. ${ }^{113}{ }^{114}$ Recently, it has been shown that disruptive mutations in SETBP1 are indeed highly penetrant (92\%) for completely absent or substantially impaired speech and language development. ${ }^{115-117}$ Due to its strong association with speech and language development SETBP1 might become of similar interest to the speech and language community comparable to FOXP2. Although the range of intellectual development ranged from normal to severe impairment in this limited amount of cases, mild ID was noted in the majority of cases. A complete lack of expressive speech with intact receptive language abilities has been noted in several individuals. In these cases active communication using gestures and mimic expression of face and body was surprisingly effective. ${ }^{113-115}$ Other features included decreased fine motor skills, subtle dysmorphisms, hyperactivity and autistic traits. ${ }^{115} 116$ Gain-of-function mutations of a hot spot region in exon 4 of SETBP1 result in a clearly different and more severe phenotype, namely the Schinzel-Giedion syndrome. ${ }^{118}$ This syndrome is characterised by profound ID, persistent feeding problems, severe forms of epilepsy, a recognisable facial gestalt, various congenital organ defects, blindness, deafness and neuroepithelial neoplasia. Most individuals die during infancy or early childhood. ${ }^{118}$

\section{TM4SF20}

A $4 \mathrm{~kb}$ deletion of TM4SF20, encoding a transmembrane protein of unknown function located at chromosome 2q36.3, has been reported to segregate with early childhood communication disorders and white matter hyperintensities (WMHs) in 15 unrelated families predominantly from South-East Asia. ${ }^{119}$ This population-specific deletion, that removes the penultimate exon 3 of TM4FS20, is highly penetrant and segregated with familial WMHs and disorders of communication. The phenotype of the majority of children included language delay without significant dysmorphisms or other congenital anomalies and with normal motor development. Formal speech/language and development assessment showed significant discrepancies between verbal and non-verbal skills. Abnormalities consistent with WMHs were observed on brain MRIs in 69\% of deletion carriers. Data from the parental carriers and extended pedigree analyses suggested that language delay convalesces over time in most individuals, potentially reflecting compensatory neuronal plasticity. ${ }^{119}$

\section{Women with fragile $\mathrm{X}$ syndrome}

Most individuals with fragile $X$ syndrome (FXS) have a loss-of-function mutation in FMR1 caused by an increased number of CGG trinucleotide repeats $(>200)$ leading to abnormal methylation of FMR1. ${ }^{120} \mathrm{FXS}$ in men is associated with moderate ID, delayed speech and language development, facial dimorphisms, macroorchidism, ASD and behaviour problems. ${ }^{120}$ In women, symptoms of FXS may be more variable in terms of behavioural and neurocognitive outcomes. ${ }^{120}$ Adult women are at increased risk for primary ovarian insufficiency and fragile $\mathrm{X}$ associated tremor/ataxia syndrome. ${ }^{120}$ Intellectual function in women may vary between normal IQ to moderate ID. Approximately 50\% of women who are heterozygous for the full mutation are intellectually normal. ${ }^{120}$ Language has been assessed in a group of girls with FXS. ${ }^{121}$ In 40\%, receptive vocabulary was well below the cut-off for language impairment. Fragile $\mathrm{X}$ testing should be considered in each child with delay of speech and language, especially in the presence of a family history of ID.

\section{Treated classic galactosaemia}

Classic galactosaemia is an autosomal recessive disorder caused by biallelic mutations in GALT (Galactose-1-Phosphate uridylyltransferase), the gene encoding galactose-1-phosphate uridyl transferase. $^{122}$ Unless a lactose-free diet is followed, classic galactosaemia leads to severe life-threatening complications 
including failure to thrive, hepatic damage, bleeding and sepsis in infants. ${ }^{123}$ Children who are treated from birth remain at increased risk for developmental delay, speech and language problems, motor disturbances and premature ovarian insufficiency. ${ }^{124}$ Mean total IQ scores were 78 and 73 at average age 10.8 years and 25.7 years, respectively. ${ }^{125}$ Speech problems starting in early childhood have been reported in up to two-thirds of individuals and continue into adulthood. ${ }^{126}$ Vocabulary and articulation problems, CAS and dysarthria have been frequently noted. ${ }^{122}$

\section{NRXN1}

Deletion of NRXN1 (Neurexin 1) on chromosome 2p13.3 has been associated with developmental delay, ASD, prominent speech and language delay, cardiac anomalies and seizures. ${ }^{127} 128$ Individuals with normal intellectual function have been reported. ${ }^{129}$ Although the phenotypical variability is large, speech delays have been noted in $78 \%$ of individuals and may also segregate in families. ${ }^{129} 130$ Additional studies are warranted to further delineate the type of language and speech defects.

\section{GRIN2A}

GRIN2A (glutamate receptor, ionotropic, N-methyl D-aspartate 2A) mutations have been reported in individuals with epilepsyaphasia spectrum disorders that include Landau-Kleffner syndrome, epileptic encephalopathy with continuous spike-wave in slow-wave sleep, atypical rolandic epilepsy with speech impairment and intermediate epilepsy-aphasia disorder. ${ }^{131}{ }^{132}$ In clinical practice, patients may first present with substantial language difficulties including verbal dyspraxia before developing seizures. In a few individuals the speech phenotype occurred in the absence of a seizure disorder. ${ }^{133}$ The GRIN2A speech phenotype includes dyspraxia, impaired motor planning and programming and dysarthria with impairment in speech execution. Most individuals with GRIN2A mutations showed normal, borderline or mildly impaired intellectual function.

\section{CONCLUSION}

Molecular genetic testing should become part of the standard evaluation of children presenting with primary speech and language pathology. Unless there is a family history or a presence of clinical key features pointing towards a specific genetic disorder, genome-wide chromosome analysis with high resolution to detect CNVs is the test of first choice (figure 1). A recent study found sex chromosome aneuploidies in $2.9-3.4 \%$ of children with oral speech and language deficits compared with $0.25 \%$ in the general population. ${ }^{9}$ Due to lack of awareness about diagnosis and management, sex chromosome trisomies remain undiagnosed in 50-90\% of cases. ${ }^{134-137}$ Early diagnosis may significantly influence psychosocial, cognitive, physiological and reproductive outcomes. ${ }^{94} 138$ It may improve an individual's quality of life and prevent serious consequences. For example, early testosterone replacement may result in increased masculinity, strength, libido, bone mineral density and body hair in men with Klinefelter syndrome. ${ }^{138}$ Similar examples of useful interventions following diagnosis of a chromosomal disorder (table 1) include otorhinolaryngological and early audiometric evaluation in 22q11.2 deletion syndrome, cardiac evaluation in several chromosomal disorders and early dietary management to prevent obesity in proximal $16 \mathrm{p} 11.2$ deletions. ${ }^{30} 5880$

In case of a normal chromosomes result, monogenic causes such as FOXP1, SETBP1 and NRXN1 may be considered. Novel single gene disorders will be defined in the near future. Existing candidate genes such as CNTNAP2, SRPX2 and KIAA0319 need further study to provide substantial evidence that they are genuine monogenic causes for primary speech and language disorders. ${ }^{132}$ 139-144 Eventually, a diagnostic custom-made next generation sequencing gene panel for primary speech and language disorders may become a useful addition to the extensive range of existing gene panels in diagnostic genetic laboratories.

Finally, referral for speech and language assessment and therapy by a speech pathologist is strongly recommended for all disorders presented in this review. A lack of consistent speech/ language therapy in affected children may lead to a significant discrepancy in vocabulary and grammatical abilities compared

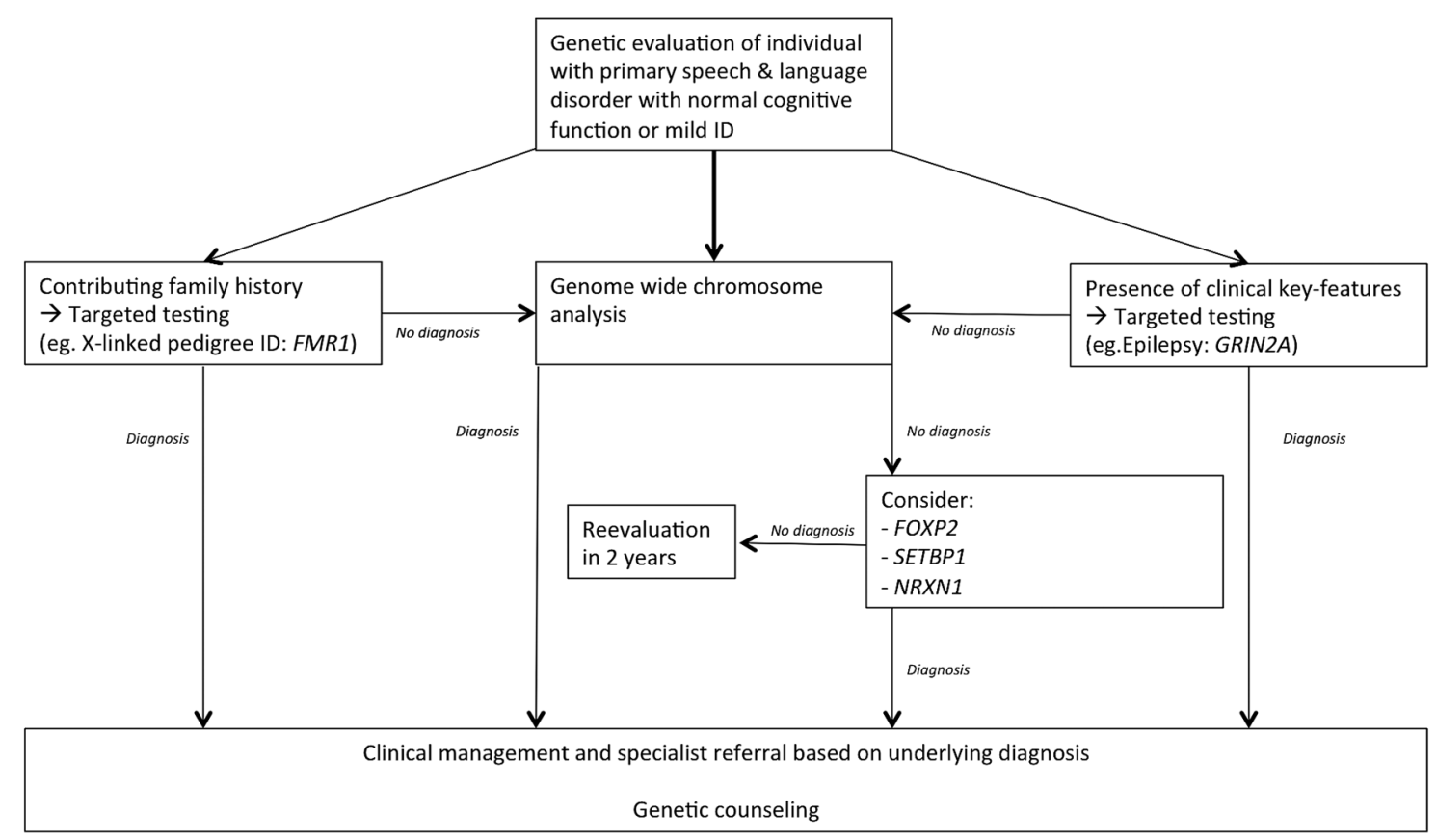

Figure 1 Diagnostic schedule for individuals presenting with primary speech and language disorder. ID, intellectual disability. 
with children who have had consistent speech/language therapy from the late infant or early toddler period. ${ }^{25} 145$ Specific speech and language interventions and augmentative communication, such as manual signing and picture-based communication, may be incorporated into children's education plans. At this stage it is not possible to provide information about tailored speech and language therapies based on the underlying disorders presented in this review. Similar to other rare genetic disorders, we are currently in an 'accumulation of knowledge phase' regarding the genetic base and exact signs and symptoms of these disorders. By defining these disorders as causes for primary speech and language pathology, we hope future studies regarding these disorders will focus more on the speech and language related signs using standardised descriptions. In this way more information will come to light and specific therapies may be developed.

Funding Ter Meulen Fonds (stipendium to BWMvB).

Competing interests None declared.

Provenance and peer review Commissioned; externally peer reviewed.

\section{REFERENCES}

1 Mefford HC, Batshaw ML, Hoffman EP. Genomics, intellectual disability, and autism. N Engl J Med 2012;366:733-43

2 Van Balkom ID, Vuijk PJ, Franssens M, Hoek HW, Hennekam RC. Development, cognition, and behaviour in Pitt-Hopkins syndrome. Dev Med Child Neurol 2012:54:925-31.

3 Van BG, Fryns JP. Angelman syndrome (AS, MIM 105830). Eur J Hum Genet 2009:17:1367-73.

4 Graham SA, Fisher SE. Decoding the genetics of speech and language. Curr Opin Neurobiol 2013;23:43-51.

5 Bishop DV, Jacobs PA, Lachlan K, Wellesley D, Barnicoat A, Boyd PA, Fryer A Middlemiss P, Smithson S, Metcalfe K, Shears D, Leggett V, Nation K, Scerif G. Autism, language and communication in children with sex chromosome trisomies. Arch Dis Child Educ Pract Ed 2011;96:954-9.

6 Deriziotis P, Fisher SE. Neurogenomics of speech and language disorders: the road ahead. Genome Biol 2013;14:204

7 Glaser B, Mumme DL, Blasey C, Morris MA, Dahoun SP, Antonarakis SE, Reiss AL, Eliez S. Language skills in children with velocardiofacial syndrome (deletion 22q11.2). J Pediatr 2002;140:753-8.

8 Somerville MJ, Mervis CB, Young EJ, Seo EJ, del Campo M, Bamforth S, Peregrine E, Loo W, Lilley M, Perez-Jurado LA, Morris CA, Scherer SW, Osborne LR. Severe expressive-language delay related to duplication of the Williams-Beuren locus. N Engl J Med 2005;353:1694-701

9 Simpson NH, Addis L, Brandler WM, Slonims V, Clark A, Watson J, Scerri TS, Hennessy ER, Bolton PF, Conti-Ramsden G, Fairfax BP, Knight JC, Stein J, Talcott JB, O'Hare A, Baird G, Paracchini S, Fisher SE, Newbury DF, Consortium SLI. Increased prevalence of sex chromosome aneuploidies in specific language impairment and dyslexia. Dev Med Child Neurol 2014;56:346-53.

10 Bishop DV. Ten questions about terminology for children with unexplained language problems. Int J Lang Commun Disord 2014:49:381-415.

11 Nelson HD, Nygren P, Walker M, Panoscha R. Screening for speech and language delay in preschool children: systematic evidence review for the US Preventive Services Task Force. Pediatrics 2006;117:e298-319.

12 Habel A, Herriot R, Kumararatne D, Allgrove J, Baker K, Baxendale H, Bu'Lock F, Firth H, Gennery A, Holland A, Illingworth C, Mercer N, Pannebakker M, Parry A, Roberts A, Tsai-Goodman B. Towards a safety net for management of 22q11.2 deletion syndrome: guidelines for our times. Eur J Pediatr 2014;173:757-65.

13 Fung WL, Butcher NJ, Costain G, Andrade DM, Boot E, Chow EW, Chung B, Cytrynbaum C, Faghfoury H, Fishman L, Garcia-Minaur S, George S, Lang AE, Repetto G, Shugar A, Silversides C, Swillen A, van Amelsvoort T, McDonald-McGinn DM, Bassett AS. Practical guidelines for managing adults with 22q11.2 deletion syndrome. Genet Med 2015. Published Online First: 8 Jan 2015

14 McDonald-McGinn DM, Emanuel BS, Zackai EH. 22q11.2 Deletion syndrome. In: Pagon RA, Adam MP, Ardinger HH, Wallace SE, Amemiya A, Bean LJH, Bird TD, Fong C-T, Smith RJH, Stephens K, eds. GeneReviews ${ }^{\circledR}$. Seattle, WA: University of Washington, 1993.

15 Aksglaede L, Link K, Giwercman A, Jorgensen N, Skakkebaek NE, Juul A. 47, XXY Klinefelter syndrome: clinical characteristics and age-specific recommendations for medical management. Am J Med Genet C Semin Med Genet 2013;163C:55-63.

16 Bondy CA, Turner Syndrome Study G. Care of girls and women with Turner syndrome: a guideline of the Turner Syndrome Study Group. J Clin Endocrinol Metab 2007;92:10-25.
17 Vulto-van Silfhout AT, Hehir-Kwa JY, van Bon BW, Schuurs-Hoeijmakers JH, Meader S, Hellebrekers CJ, Thoonen IJ, de Brouwer AP, Brunner HG, Webber C, Pfundt $\mathrm{R}$, de Leeuw N, de Vries BB. Clinical significance of de novo and inherited copy-number variation. Hum Mutat 2013;34:1679-87.

18 Carter MT, Nikkel SM, Fernandez BA, Marshall CR, Noor A, Lionel AC, Prasad A, Pinto D, Joseph-George AM, Noakes C, Fairbrother-Davies C, Roberts W, Vincent J, Weksberg R, Scherer SW. Hemizygous deletions on chromosome 1p21.3 involving the DPYD gene in individuals with autism spectrum disorder. Clin Genet 2011:80:435-43

19 Willemsen MH, Valles A, Kirkels LA, Mastebroek M, Olde Loohuis N, Kos A, Wissink-Lindhout WM, de Brouwer AP, Nillesen WM, Pfundt R, Holder-Espinasse $M$, Vallee L, Andrieux J, Coppens-Hofman MC, Rensen H, Hamel BC, van Bokhoven $\mathrm{H}$, Aschrafi A, Kleefstra T. Chromosome 1p21.3 microdeletions comprising DPYD and MIR137 are associated with intellectual disability. J Med Genet 2011:48:810-18.

20 Duan J, Shi J, Fiorentino A, Leites C, Chen X, Moy W, Chen J, Alexandrov BS, Usheva A, He D, Freda J, O'Brien NL, Molecular Genetics of Schizophrenia C, Genomic Psychiatric Cohort c, McQuillin A, Sanders AR, Gershon ES, DeLisi LE, Bishop AR, Gurling HM, Pato MT, Levinson DF, Kendler KS, Pato CN, Gejman PV. A rare functional noncoding variant at the GWAS-implicated MIR137/MIR2682 locus might confer risk to schizophrenia and bipolar disorder. Am J Hum Genet 2014:95:744-53.

21 Williams JC, Barratt-Boyes BG, Lowe JB. Supravalvular aortic stenosis. Circulation 1961:24:1311-18.

22 Beuren AJ, Apitz J, Harmjanz D. Supravalvular aortic stenosis in association with mental retardation and a certain facial appearance. Circulation $1962 ; 26: 1235-40$

23 Van der Aa N, Rooms L, Vandeweyer G, van den Ende J, Reyniers E, Fichera M, Romano C, Delle Chiaie B, Mortier G, Menten B, Destree A, Maystadt I, Mannik K, Kurg A, Reimand T, McMullan D, Oley C, Brueton L, Bongers EM, van Bon BW Pfund $R$, Jacquemont $S$, Ferrarini $A$, Martinet $D$, Schrander-Stumpel $C$, Stegmann AP, Frints SG, de Vries BB, Ceulemans B, Kooy RF. Fourteen new cases contribute to the characterization of the 7q11.23 microduplication syndrome. Eur J Med Genet 2009;52:94-100

24 Berg JS, Brunetti-Pierri N, Peters SU, Kang SH, Fong CT, Salamone J, Freedenberg $D$, Hannig VL, Prock LA, Miller DT, Raffalli P, Harris DJ, Erickson RP, Cunniff C, Clark GD, Blazo MA, Peiffer DA, Gunderson KL, Sahoo T, Patel A, Lupski JR, Beaudet AL, Cheung SW. Speech delay and autism spectrum behaviors are frequently associated with duplication of the 7q11.23 Williams-Beuren syndrome region. Genet Med 2007;9:427-41.

25 Velleman SL, Mervis CB. Children with 7q11.23 Duplication Syndrome: Speech, Language, Cognitive, and Behavioral Characteristics and their Implications for Intervention. Perspect Lang Learn Educ 2011;18:108-16.

26 Parrott A, James J, Goldenberg P, Hinton RB, Miller E, Shikany A, Aylsworth AS, Kaiser-Rogers K, Ferns SJ, Lalani SR, Ware SM. Aortopathy in the 7q11.23 microduplication syndrome. Am J Med Genet A 2015:167A:363-70.

27 Dixit A, McKee S, Mansour S, Mehta SG, Tanteles GA, Anastasiadou V, Patsalis PC, Martin K, McCullough S, Suri M, Sarkar A. 7q11.23 Microduplication: a recognizable phenotype. Clin Genet 2013;83:155-61.

28 Morris CA, Mervis CB, Hobart HH, Gregg RG, Bertrand J, Ensing GJ, Sommer A, Moore CA, Hopkin RJ, Spallone PA, Keating MT, Osborne L, Kimberley KW, Stock AD. GTF2I hemizygosity implicated in mental retardation in Williams syndrome: genotype-phenotype analysis of five families with deletions in the Williams syndrome region. Am J Med Genet A 2003;123A:45-59.

29 Mervis CB, Dida J, Lam E, Crawford-Zelli NA, Young EJ, Henderson DR, Onay T, Morris CA, Woodruff-Borden J, Yeomans J, Osborne LR. Duplication of GTF2I results in separation anxiety in mice and humans. Am J Hum Genet 2012;90:1064-70.

30 van Bon BW, Balciuniene J, Fruhman G, Nagamani SC, Broome DL, Cameron E, Martinet $D$, Roulet $E$, Jacquemont $S$, Beckmann JS, Irons $M$, Potocki L, Lee $B$, Cheung SW, Patel A, Bellini $M$, Selicorni $A$, Ciccone $R$, Silengo $M$, Vetro A, Knoers $N V$, de Leeuw N, Pfundt R, Wolf B, Jira P, Aradhya S, Stankiewicz P, Brunner HG, Zuffardi O, Selleck SB, Lupski JR, de Vries BB. The phenotype of recurrent 10q22q23 deletions and duplications. Eur J Hum Genet 2011;19:400-8.

31 Balciuniene J, Feng N, lyadurai $K$, Hirsch $B$, Charnas L, Bill BR, Easterday MC, Staaf J, Oseth L, Czapansky-Beilman D, Avramopoulos D, Thomas GH, Borg A, Valle D, Schimmenti LA, Selleck SB. Recurrent 10q22-q23 deletions: a genomic disorder on $10 \mathrm{q}$ associated with cognitive and behavioral abnormalities. Am J Hum Genet 2007;80:938-47.

32 Alliman S, Coppinger J, Marcadier J, Thiese H, Brock P, Shafer S, Weaver C, Asamoah A, Leppig K, Dyack S, Morash B, Schultz R, Torchia BS, Lamb AN Bejjani BA. Clinical and molecular characterization of individuals with recurrent genomic disorder at 10q22.3q23.2. Clin Genet 2010;78:162-8.

33 Menko FH, Kneepkens CM, de LN, Peeters EA, Van ML, Kamsteeg EJ, Davidson R, Rozendaal L, Lasham CA, Peeters-Scholte CM, Jansweijer MC, Hilhorst-Hofstee Y, Gille JJ, Heins YM, Nieuwint AW, Sistermans EA. Variable phenotypes associated with 10q23 microdeletions involving the PTEN and BMPR1A genes. Clin Genet 2008;74:145-54. 
34 Merg A, Howe JR. Genetic conditions associated with intestinal juvenile polyps. Am J Med Genet C Semin Med Genet 2004;129C:44-55.

35 Schanze I, Schanze D, Bacino CA, Douzgou S, Kerr B, Zenker M. Haploinsufficiency of SOX5, a member of the SOX (SRY-related HMG-box) family of transcription factors is a cause of intellectual disability. Eur J Med Genet 2013;56:108-13.

36 Lee RW, Bodurtha J, Cohen J, Fatemi A, Batista D. Deletion 12p12 involving SoX5 in two children with developmental delay and dysmorphic features. Pediatr Neurol 2013:48:317-20

37 Lamb AN, Rosenfeld JA, Neill NJ, Talkowski ME, Blumenthal I, Girirajan S, Keelean-Fuller D, Fan Z, Pouncey J, Stevens C, Mackay-Loder L, Terespolsky D, Bader PI, Rosenbaum K, Vallee SE, Moeschler JB, Ladda R, Sell S, Martin J, Ryan $S$, Jones MC, Moran R, Shealy A, Madan-Khetarpal S, McConnell J, Surti U, Delahaye A, Heron-Longe B, Pipiras E, Benzacken B, Passemard S, Verloes A, Isidor B, Le Caignec C, Glew GM, Opheim KE, Descartes M, Eichler EE, Morton CC, Gusella JF, Schultz RA, Ballif BC, Shaffer LG. Haploinsufficiency of SOX5 at 12 p12.1 is associated with developmental delays with prominent language delay, behavior problems, and mild dysmorphic features. Hum Mutat 2012;33:728-40.

38 Thevenon J, Callier P, Andrieux J, Delobel B, David A, Sukno S, Minot D, Mosca Anne L, Marle N, Sanlaville D, Bonnet M, Masurel-Paulet A, Levy F, Gaunt L, Farrell S, Le Caignec C, Toutain A, Carmignac V, Mugneret F, Clayton-Smith J, Thauvin-Robinet C, Faivre L. 12p13.33 microdeletion including ELKS/ERC1, a new locus associated with childhood apraxia of speech. Eur J Hum Genet 2013:21:82-8.

39 Zody MC, Garber M, Sharpe T, Young SK, Rowen L, O'Neill K, Whittaker CA, Kamal M, Chang JL, Cuomo CA, Dewar K, FitzGerald MG, Kodira CD, Madan A, Qin S, Yang X, Abbasi N, Abouelleil A, Arachchi HM, Baradarani L, Birditt B, Bloom S, Bloom T, Borowsky ML, Burke J, Butler J, Cook A, DeArellano K, DeCaprio D, Dorris L III, Dors M, Eichler EE, Engels R, Fahey J, Fleetwood P, Friedman C, Gearin G, Hall JL, Hensley G, Johnson E, Jones C, Kamat A, Kaur A, Locke DP, Munson G, Jaffe DB, Lui A, Macdonald P, Mauceli E, Naylor JW, Nesbitt R, Nicol R, O'Leary SB, Ratcliffe A, Rounsley $S$, She $X$, Sneddon KM, Stewart S, Sougnez C, Stone SM, Topham K, Vincent D, Wang S, Zimmer AR, Birren BW, Hood L, Lander ES, Nusbaum C. Analysis of the DNA sequence and duplication history of human chromosome 15. Nature 2006;440:671-5.

40 Makoff AJ, Flomen RH. Detailed analysis of 15q11-q14 sequence corrects errors and gaps in the public access sequence to fully reveal large segmental duplications at breakpoints for Prader-Willi, Angelman, and inv dup(15) syndromes. Genome Biol 2007:8:R114.

41 Burnside RD, Pasion R, Mikhail FM, Carroll AJ, Robin NH, Youngs EL, Gadi IK, Keitges E, Jaswaney VL, Papenhausen PR, Potluri VR, Risheg H, Rush B, Smith JL, Schwartz S, Tepperberg JH, Butler MG. Microdeletion/microduplication of proximal $15 q 11.2$ between BP1 and BP2: a susceptibility region for neurological dysfunction including developmental and language delay. Hum Genet 2011;130:517-28

42 Cox DM, Butler MG. The 15q11.2 BP1-BP2 microdeletion syndrome: a review. Int J Mol Sci 2015;16:4068-82.

43 Vanlerberghe $C$, Petit F, Malan V, Vincent-Delorme C, Bouquillon S, Boute 0 Holder-Espinasse M, Delobel B, Duban B, Vallee L, Cuisset JM, Lemaitre MP, Vantyghem MC, Pigeyre M, Lanco-Dosen S, Plessis G, Gerard M, Decamp M, Mathieu M, Morin G, Jedraszak G, Bilan F, Gilbert-Dussardier B, Fauvert D, Roume J, Cormier-Daire V, Caumes R, Puechberty J, Genevieve D, Sarda P, Pinson L, Blanchet $\mathrm{P}$, Lemeur N, Sheth F, Manouvrier-Hanu S, Andrieux J. 15q11.2 microdeletion (BP1-BP2) and developmental delay, behaviour issues, epilepsy and congenital heart disease: A series of 52 patients. Eur J Med Genet 2015:58:140-7.

44 Varela MC, Kok F, Otto PA, Koiffmann CP. Phenotypic variability in Angelman syndrome: comparison among different deletion classes and between deletion and UPD subjects. Eur J Hum Genet 2004;12:987-92.

45 Chai JH, Locke DP, Greally JM, Knoll JH, Ohta T, Dunai J, Yavor A, Eichler EE, Nicholls RD. Identification of four highly conserved genes between breakpoint hotspots BP1 and BP2 of the Prader-Willi/Angelman syndromes deletion region that have undergone evolutionary transposition mediated by flanking duplicons. Am J Hum Genet 2003;73:898-925.

46 Soemedi R, Wilson IJ, Bentham J, Darlay R, Topf A, Zelenika D, Cosgrove C, Setchfield K, Thornborough C, Granados-Riveron J, Blue GM, Breckpot J, Hellens S, Zwolinkski S, Glen E, Mamasoula C, Rahman TJ, Hall D, Rauch A, Devriendt K, Gewillig M, O' Sullivan J, Winlaw DS, Bu'Lock F, Brook JD, Bhattacharya S, Lathrop M, Santibanez-Koref M, Cordell HJ, Goodship JA, Keavney BD. Contribution of global rare copy-number variants to the risk of sporadic congenital heart disease. Am J Hum Genet 2012;91:489-501.

47 Roberts SE, Dennis NR, Browne CE, Willatt L, Woods G, Cross I, Jacobs PA, Thomas $S$. Characterisation of interstitial duplications and triplications of chromosome 15q11-q13. Hum Genet 2002;110:227-34.

48 Boyar FZ, Whitney MM, Lossie AC, Gray BA, Keller KL, Stalker HJ, Zori RT, Geffken G, Mutch J, Edge PJ, Voeller KS, Williams CA, Driscoll DJ. A family with a grand-maternally derived interstitial duplication of proximal 15q. Clin Genet 2001;60:421-30.
49 Al Ageeli E, Drunat S, Delanoe C, Perrin L, Baumann C, Capri Y, Fabre-Teste J, Aboura A, Dupont C, Auvin S, El Khattabi L, Chantereau D, Moncla A, Tabet AC, Verloes A. Duplication of the 15q11-q13 region: clinical and genetic study of 30 new cases. Eur J Med Genet 2014;57:5-14.

50 Urraca N, Cleary J, Brewer V, Pivnick EK, McVicar K, Thibert RL, Schanen NC, Esmer C, Lamport D, Reiter LT. The interstitial duplication 15q11.2-q13 syndrome includes autism, mild facial anomalies and a characteristic EEG signature. Autism Res 2013;6:268-79.

51 Bolton PF, Dennis NR, Browne CE, Thomas NS, Veltman MW, Thompson RJ, Jacobs $P$. The phenotypic manifestations of interstitial duplications of proximal $15 q$ with special reference to the autistic spectrum disorders. Am J Med Genet 2001:105:675-85.

52 Browne CE, Dennis NR, Maher E, Long FL, Nicholson JC, Sillibourne J, Barber JC. Inherited interstitial duplications of proximal 15q: genotype-phenotype correlations. Am J Hum Genet 1997:61:1342-52.

53 Shaaya EA, Pollack SF, Boronat S, Davis-Cooper S, Zella GC, Thibert RL. Gastrointestinal problems in 15q duplication syndrome. Eur J Med Genet 2015;58:191-3.

54 Shinawi M, Liu P, Kang SH, Shen J, Belmont JW, Scott DA, Probst FJ, Craigen WJ, Graham B, Pursley A, Clark G, Lee J, Proud M, Stocco A, Rodriguez D, Kozel B, Sparagana S, Roeder E, McGrew S, Kurczynski T, Allison L, Amato S, Savage S, Patel A, Stankiewicz P, Beaudet A, Cheung SW, Lupski JR. Recurrent reciprocal $16 p 11.2$ rearrangements associated with global developmental delay, behavioral problems, dysmorphism, epilepsy, and abnormal head size. J Med Genet 2009:47:332-41.

55 Rosenfeld JA, Coppinger J, Bejjani BA, Girirajan S, Eichler EE, Shaffer LG, Ballif $B C$. Speech delays and behavioral problems are the predominant features in individuals with developmental delays and 16p11.2 microdeletions and microduplications. J Neurodev Disord 2010:2:26-38.

56 Walters RG, Jacquemont S, Valsesia A, de Smith AJ, Martinet D, Andersson J, Falchi $M$, Chen F, Andrieux J, Lobbens S, Delobel B, Stutzmann F, El-Sayed Moustafa JS, Chevre JC, Lecoeur C, Vatin V, Bouquillon S, Buxton JL, Boute 0 Holder-Espinasse M, Cuisset JM, Lemaitre MP, Ambresin AE, Brioschi A, Gaillard M, Giusti V, Fellmann F, Ferrarini A, Hadjikhani N, Campion D, Guilmatre A, Goldenberg A, Calmels N, Mandel JL, Le CC, David A, Isidor B, Cordier MP, Dupuis-Girod S, Labalme A, Sanlaville $D$, Beri-Dexheimer $M$, Jonveaux $P$, LeHeup B, Ounap K, Bochukova EG, Henning E, Keogh J, Ellis RJ, Macdermot KD, van Haelst MM, Vincent-Delorme C, Plessis G, Touraine R, Philippe A, Malan V, Mathieu-Dramard M, Chiesa J, Blaumeiser B, Kooy RF, Caiazzo R, Pigeyre M, Balkau B, Sladek R, Bergmann S, Mooser V, Waterworth D, Reymond A, Vollenweider P, Waeber G, Kurg A, Palta P, Esko T, Metspalu A, Nelis M, Elliott P, Hartikainen AL, McCarthy Ml, Peltonen L, Carlsson L, Jacobson P, Sjostrom L, Huang N, Hurles ME, O'Rahilly S, Farooqi IS, Mannik K, Jarvelin MR, Pattou F Meyre D, Walley AJ, Coin LJ, Blakemore Al, Froguel P, Beckmann JS. A new highly penetrant form of obesity due to deletions on chromosome 16p11.2. Nature 2010;463:671-5.

57 Yu Y, Zhu H, Miller DT, Gusella JF, Platt OS, Wu BL, Shen Y, Children's Hospital Boston Genotype Phenotype Study G. Age- and gender-dependent obesity in individuals with 16p11.2 deletion. J Genet Genomics 2011;38:403-9.

58 Miller DT, Nasir R, Sobeih MM, Shen Y, Wu BL, Hanson E. 16p11.2 Microdeletion. In: Pagon RA, Adam MP, Ardinger HH, Wallace SE, Amemiya A, Bean LJH, Bird TD, Fong C-T, Smith RJH, Stephens K, eds. GeneReviews ${ }^{\circledR}$. Seattle, WA: University of Washington, 1993.

59 Raca G, Baas BS, Kirmani S, Laffin JJ, Jackson CA, Strand EA, Jakielski KJ Shriberg LD. Childhood Apraxia of Speech (CAS) in two patients with $16 \mathrm{p} 11.2$ microdeletion syndrome. Eur J Hum Genet 2013;21:455-9.

60 Laffin JJ, Raca G, Jackson CA, Strand EA, Jakielski KJ, Shriberg LD. Novel candidate genes and regions for childhood apraxia of speech identified by array comparative genomic hybridization. Genet Med 2012;14:928-36.

61 Hanson E, Bernier R, Porche K, Jackson Fl, Goin-Kochel RP, Snyder LG, Snow AV Wallace AS, Campe KL, Zhang Y, Chen Q, D'Angelo D, Moreno-De-Luca A, Orr PT, Boomer KB, Evans DW, Kanne S, Berry L, Miller FK, Olson J, Sherr E, Martin $C L$, Ledbetter DH, Spiro JE, Chung WK, on behalf of the Simons Variation in Individuals Project C. The cognitive and behavioral phenotype of the $16 \mathrm{p} 11.2$ deletion in a clinically ascertained population. Biol Psychiatry 2015;77:785-93.

62 Zufferey F, Sherr EH, Beckmann ND, Hanson E, Maillard AM, Hippolyte L, Mace A, Ferrari C, Kutalik Z, Andrieux J, Aylward E, Barker M, Bernier R, Bouquillon S, Conus P, Delobel B, Faucett WA, Goin-Kochel RP, Grant E, Harewood L, Hunter JV, Lebon S, Ledbetter DH, Martin CL, Mannik K, Martinet D, Mukherjee P, Ramocki MB, Spence SJ, Steinman KJ, Tjernagel J, Spiro JE, Reymond A, Beckmann JS, Chung WK, Jacquemont S, Simons VIPC, p11.2 European C. A 600 $\mathrm{kb}$ deletion syndrome at $16 \mathrm{p} 11.2$ leads to energy imbalance and neuropsychiatric disorders. J Med Genet 2012;49:660-8.

63 Moreno-De-Luca A, Evans DW, Boomer KB, Hanson E, Bernier R, Goin-Kochel RP, Myers SM, Challman TD, Moreno-De-Luca D, Slane MM, Hare AE, Chung WK, Spiro JE, Faucett WA, Martin CL, Ledbetter DH. The role of parental cognitive, behavioral, and motor profiles in clinical variability in individuals with chromosome 16p11.2 deletions. JAMA Psychiatry 2015;72:119-26. 
64 Gerundino F, Marseglia G, Pescucci C, Pelo E, Benelli M, Giachini C, Federighi B, Antonelli C, Torricelli F. 16p11.2 de novo microdeletion encompassing SRCAP gene in a patient with speech impairment, global developmental delay and behavioural problems. Eur J Med Genet 2014;57:649-53.

65 Nakamine $A$, Ouchanov L, Jimenez $P$, Manghi ER, Esquivel M, Monge S, Fallas M, Burton BK, Szomju B, Elsea SH, Marshall CR, Scherer SW, McInnes LA. Duplication of $17(\mathrm{p} 11.2 \mathrm{p} 11.2)$ in a male child with autism and severe language delay. Am J Med Genet A 2008;146A:636-43.

66 Potocki L, Bi W, Treadwell-Deering D, Carvalho CM, Eifert A, Friedman EM, Glaze $D$, Krull K, Lee JA, Lewis RA, Mendoza-Londono R, Robbins-Furman P, Shaw C, Shi X, Weissenberger G, Withers M, Yatsenko SA, Zackai EH, Stankiewicz P, Lupski JR. Characterization of Potocki-Lupski syndrome (dup(17)(p11.2p11.2)) and delineation of a dosage-sensitive critical interval that can convey an autism phenotype. Am J Hum Genet 2007;80:633-49.

67 Treadwell-Deering DE, Powell MP, Potocki L. Cognitive and behavioral characterization of the Potocki-Lupski syndrome (duplication 17p11.2). J Dev Behav Pediatr 2010;31:137-43.

68 Jefferies JL, Pignatelli RH, Martinez HR, Robbins-Furman PJ, Liu P, Gu W, Lupski $J R$, Potocki L. Cardiovascular findings in duplication 17p11.2 syndrome. Genet Med 2012;14:90-4.

69 Yusupov R, Roberts AE, Lacro RV, Sandstrom M, Ligon AH. Potocki-Lupski syndrome: an inherited dup(17)(p11.2p11.2) with hypoplastic left heart. Am J Med Genet A 2011;155A:367-71.

70 Magoulas PL, Liu P, Gelowani V, Soler-Alfonso C, Kivuva EC, Lupski JR, Potocki L. Inherited dup(17)(p11.2p11.2): expanding the phenotype of the Potocki-Lupski syndrome. Am J Med Genet A 2014;164A:500-4.

71 Gulhan Ercan-Sencicek A, Davis Wright NR, Frost SJ, Fulbright RK, Felsenfeld S, Hart L, Landi N, Einar Mencl W, Sanders SJ, Pugh KR, State MW, Grigorenko EL. Searching for Potocki-Lupski syndrome phenotype: a patient with language impairment and no autism. Brain Dev 2012;34:700-3.

72 Hall JG. CATCH 22. J Med Genet 1993;30:801-2.

73 Kobrynski LJ, Sullivan KE. Velocardiofacial syndrome, DiGeorge syndrome: the chromosome 22q11.2 deletion syndromes. Lancet 2007;370:1443-52.

74 Ryan AK, Goodship JA, Wilson DI, Philip N, Levy A, Seidel H, Schuffenhauer S, Oechsler H, Belohradsky B, Prieur M, Aurias A, Raymond FL, Clayton-Smith J, Hatchwell E, McKeown C, Beemer FA, Dallapiccola B, Novelli G, Hurst JA, Ignatius J, Green AJ, Winter RM, Brueton L, Brondum-Nielsen K, Scambler PJ. Spectrum of clinical features associated with interstitial chromosome 22q11 deletions: a European collaborative study. J Med Genet 1997:34:798-804.

75 Swillen A, Vogels A, Devriendt K, Fryns JP. Chromosome 22q11 deletion syndrome: update and review of the clinical features, cognitive-behavioral spectrum, and psychiatric complications. Am J Med Genet 2000;97:128-35.

76 Devriendt K, Fryns JP, Mortier G, van Thienen MN, Keymolen K. The annual incidence of DiGeorge/velocardiofacial syndrome. J Med Genet 1998:35:789-90.

77 McDonald-McGinn DM EB, Zackai EH. 22q11.2 Deletion Syndrome. Pagon RA, Adam MP, Ardinger HH, Wallace SE, Amemiya A, Bean LJH, Bird TD, Fong C-T, Smith RJH, Stephens K, eds. GeneReviews ${ }^{\circledR}$ [Internet]. Seattle, WA: University of Washington, 1993-2014. http://wwwncbinlmnihgov/books/NBK1523/1999

78 Donald-McGinn DM, Kirschner R, Goldmuntz E, Sullivan K, Eicher P, Gerdes M, Moss E, Solot C, Wang P, Jacobs I, Handler S, Knightly C, Heher K, Wilson M, Ming JE, Grace K, Driscoll D, Pasquariello P, Randall P, LaRossa D, Emanuel BS, Zackai EH. The Philadelphia story: the 22q11.2 deletion: report on 250 patients. Genet Couns 1999;10:11-24.

79 Digilio MC, Marino B, Giannotti A, Dallapiccola B. Familial deletions of chromosome 22q11. Am J Med Genet 1997:73:95-6.

80 Cancrini C, Puliafito P, Digilio MC, Soresina A, Martino S, Rondelli R, Consolini R, Ruga EM, Cardinale F, Finocchi A, Romiti ML, Martire B, Bacchetta R, Albano V, Carotti A, Specchia F, Montin D, Cirillo E, Cocchi G, Trizzino A, Bossi G, Milanesi O, Azzari C, Corsello G, Pignata C, Aiuti A, Pietrogrande MC, Marino B, Ugazio AG, Plebani A, Rossi P, Italian Network for Primary I. Clinical features and follow-up in patients with 22q11.2 deletion syndrome. J Pediatr 2014:164:1475-80 e2.

81 Persson C, Friman V, Oskarsdottir S, Jonsson R. Speech and hearing in adults with 22q11.2 deletion syndrome. Am J Med Genet A 2012;158A:3071-9.

82 Widdershoven JC, Beemer FA, Kon M, Dejonckere PH, Mink van der Molen AB. Possible mechanisms and gene involvement in speech problems in the 22q11.2 deletion syndrome. J Plas Reconstr Aesthet Surg 2008;61:1016-23.

83 Ben-Shachar S, Ou Z, Shaw CA, Belmont JW, Patel MS, Hummel M, Amato S, Tartaglia N, Berg J, Sutton VR, Lalani SR, Chinault AC, Cheung SW, Lupski JR, Patel A. 22q11.2 distal deletion: a recurrent genomic disorder distinct from DiGeorge syndrome and velocardiofacial syndrome. Am J Hum Genet 2008;82:214-21.

84 Rauch A, Zink S, Zweier C, Thiel CT, Koch A, Rauch R, Lascorz J, Huffmeier U, Weyand $M$, Singer $H$, Hofbeck M. Systematic assessment of atypical deletions reveals genotype-phenotype correlation in 22q11.2. J Med Genet 2005;42:871-6.

85 Rodningen OK, Prescott T, Eriksson AS, Rosby 0. 1.4Mb recurrent 22q11.2 distal deletion syndrome, two new cases expand the phenotype. Eur J Med Genet 2008;51:646-50.
86 Saitta SC, McGrath JM, Mensch H, Shaikh TH, Zackai EH, Emanuel BS. A 22q11.2 deletion that excludes UFD1L and CDC45L in a patient with conotruncal and craniofacial defects. Am J Hum Genet 1999;65:562-6.

87 Fagerberg CR, Graakjaer J, Heinl UD, Ousager LB, Dreyer I, Kirchhoff M, Rasmussen AA, Lautrup CK, Birkebaek N, Sorensen K. Heart defects and other features of the 22q11 distal deletion syndrome. Eur J Med Genet 2013;56:98-107.

88 Mikhail FM, Burnside RD, Rush B, Ibrahim J, Godshalk R, Rutledge SL, Robin NH Descartes MD, Carroll AJ. The recurrent distal 22q11.2 microdeletions are often de novo and do not represent a single clinical entity: a proposed categorization system. Genet Med 2014;16:92-100.

89 Jackson EM, Shaikh TH, Gururangan S, Jones MC, Malkin D, Nikkel SM, Zuppan CW, Wainwright LM, Zhang F, Biegel JA. High-density single nucleotide polymorphism array analysis in patients with germline deletions of 22q11.2 and malignant rhabdoid tumor. Hum Genet 2007;122:117-27.

90 Morris JK, Alberman E, Scott C, Jacobs P. Is the prevalence of Klinefelter syndrome increasing? Eur J Hum Genet 2008;16:163-70.

91 Leggett V, Jacobs P, Nation K, Scerif G, Bishop DV. Neurocognitive outcomes of individuals with a sex chromosome trisomy: $X X X, X Y Y$, or $X X Y$ : a systematic review. Dev Med Child Neurol 2010:52:119-29.

92 Fullerton G, Hamilton M, Maheshwari A. Should non-mosaic Klinefelter syndrome men be labelled as infertile in 2009? Human Reprod 2010;25:588-97.

93 Hong DS, Reiss AL. Cognitive and neurological aspects of sex chromosome aneuploidies. The Lancet Neurology 2014;13:306-18.

94 Tartaglia NR, Howell S, Sutherland A, Wilson R, Wilson L. A review of trisomy X (47,XXX). Orphanet J Rare Dis 2010;5:8.

95 Mazzocco MM. The cognitive phenotype of Turner syndrome: Specific learning disabilities. Int Cong Ser 2006:1298:83-92.

96 Temple CM. Oral fluency and narrative production in children with Turner's syndrome. Neuropsychologia 2002;40:1419-27.

97 Temple CM, Shephard EE. Exceptional lexical skills but executive language deficits in school starters and young adults with Turners syndrome: implications for $X$ chromosome effects on brain function. Brain Lang 2012;120:345-59.

98 Starke M, Albertsson Wikland K, Moller A. Parents' descriptions of development and problems associated with infants with Turner syndrome: a retrospective study. J Paediatr Child Health 2003;39:293-8.

99 Jacobs PA, Betts PR, Cockwell AE, Crolla JA, Mackenzie MJ, Robinson DO, Youings SA. A cytogenetic and molecular reappraisal of a series of patients with Turner's syndrome. Ann Hum Genet 1990;54(Pt 3):209-23.

100 Lai CS, Fisher SE, Hurst JA, Vargha-Khadem F, Monaco AP. A forkhead-domain gene is mutated in a severe speech and language disorder. Nature 2001:413:519-23.

101 Zeesman S, Nowaczyk MJ, Teshima I, Roberts W, Cardy JO, Brian J, Senman L, Feuk L, Osborne LR, Scherer SW. Speech and language impairment and oromotor dyspraxia due to deletion of 7q31 that involves FOXP2. Am J Med Genet A 2006;140:509-14.

102 Rice GM, Raca G, Jakielski KJ, Laffin JJ, lyama-Kurtycz CM, Hartley SL, Sprague RE, Heintzelman AT, Shriberg LD. Phenotype of FOXP2 haploinsufficiency in a mother and son. Am J Med Genet A 2012;158A:174-81.

103 Fisher SE, Vargha-Khadem F, Watkins KE, Monaco AP, Pembrey ME. Localisation of a gene implicated in a severe speech and language disorder. Nat Genet 1998:18:168-70.

104 Fisher SE, Scharff C. FOXP2 as a molecular window into speech and language. Trends Genet 2009;25:166-77.

105 MacDermot KD, Bonora E, Sykes N, Coupe AM, Lai CS, Vernes SC Vargha-Khadem F, McKenzie F, Smith RL, Monaco AP, Fisher SE. Identification of FOXP2 truncation as a novel cause of developmental speech and language deficits. Am J Hum Genet 2005;76:1074-80.

106 Vargha-Khadem F, Watkins KE, Price CJ, Ashburner J, Alcock KJ, Connelly A, Frackowiak RS, Friston KJ, Pembrey ME, Mishkin M, Gadian DG, Passingham RE. Neural basis of an inherited speech and language disorder. Proc Natl Acad Sci USA 1998;95:12695-700.

107 Turner SJ, Hildebrand MS, Block S, Damiano J, Fahey M, Reilly S, Bahlo M, Scheffer IE, Morgan AT. Small intragenic deletion in FOXP2 associated with childhood apraxia of speech and dysarthria. Am J Med Genet $A$ 2013;161A:2321-6.

108 Shu W, Lu MM, Zhang Y, Tucker PW, Zhou D, Morrisey EE. Foxp2 and Foxp1 cooperatively regulate lung and esophagus development. Development 2007;134:1991-2000.

109 Teramitsu I, Kudo LC, London SE, Geschwind DH, White SA. Parallel FoxP1 and FoxP2 expression in songbird and human brain predicts functional interaction. J Neurosci 2004:24:3152-63.

110 Horn D, Kapeller J, Rivera-Brugues N, Moog U, Lorenz-Depiereux B, Eck S, Hempe M, Wagenstaller J, Gawthrope A, Monaco AP, Bonin M, Riess O, Wohlleber E, Illig T, Bezzina CR, Franke A, Spranger S, Villavicencio-Lorini P, Seifert W, Rosenfeld J, Klopocki E, Rappold GA, Strom TM. Identification of FOXP1 deletions in three unrelated patients with mental retardation and significant speech and language deficits. Hum Mutat 2010;31:E1851-60. 
111 Le Fevre AK, Taylor S, Malek NH, Horn D, Carr CW, Abdul-Rahman OA, O'Donnell S, Burgess T, Shaw M, Gecz J, Bain N, Fagan K, Hunter MF. FOXP1 mutations cause intellectual disability and a recognizable phenotype. Am J Med Genet $A$ 2013:161A:3166-75.

112 Hamdan FF, Daoud H, Rochefort D, Piton A, Gauthier J, Langlois M, Foomani G, Dobrzeniecka S, Krebs MO, Joober R, Lafreniere RG, Lacaille JC, Mottron L, Drapeau P, Beauchamp MH, Phillips MS, Fombonne E, Rouleau GA, Michaud JL. De novo mutations in FOXP1 in cases with intellectual disability, autism, and language impairment. Am J Hum Genet 2010;87:671-8.

113 Filges I, Shimojima K, Okamoto N, Rothlisberger B, Weber P, Huber AR, Nishizawa T, Datta AN, Miny P, Yamamoto T. Reduced expression by SETBP1 haploinsufficiency causes developmental and expressive language delay indicating a phenotype distinct from Schinzel-Giedion syndrome. J Med Genet 2011;48:117-22.

114 Marseglia G, Scordo MR, Pescucci C, Nannetti G, Biagini E, Scandurra V, Gerundino F, Magi A, Benelli M, Torricelli F. 372 kb microdeletion in 18q12.3 causing SETBP1 haploinsufficiency associated with mild mental retardation and expressive speech impairment. Eur J Med Genet 2012;55:216-21.

115 Coe BP, Witherspoon K, Rosenfeld JA, van Bon BW, Vulto-van Silfhout AT, Bosco $P$, Friend $K L$, Baker $C$, Buono $S$, Vissers LE, Schuurs-Hoeijmakers JH, Hoischen $A$, Pfundt R, Krumm N, Carvill GL, Li D, Amaral D, Brown N, Lockhart PJ, Scheffer IE, Alberti A, Shaw M, Pettinato R, Tervo R, de Leeuw N, Reijnders MR, Torchia BS, Peeters H, Thompson E, O'Roak BJ, Fichera M, Hehir-Kwa JY, Shendure J, Mefford HC, Haan E, Gecz J, de Vries BB, Romano C, Eichler EE. Refining analyses of copy number variation identifies specific genes associated with developmental delay. Nat Genet 2014:46:1063-71.

116 Rauch A, Wieczorek D, Graf E, Wieland T, Endele S, Schwarzmayr T, Albrecht B, Bartholdi D, Beygo J, Di Donato N, Dufke A, Cremer K, Hempel M, Horn D, Hoyer J, Joset P, Ropke A, Moog U, Riess A, Thiel CT, Tzschach A, Wiesener A, Wohlleber $E$, Zweier $C$, Ekici AB, Zink AM, Rump A, Meisinger $C$, Grallert $H$, Sticht $H$, Schenck A, Engels H, Rappold G, Schrock E, Wieacker P, Riess O, Meitinger T, Reis A, Strom TM. Range of genetic mutations associated with severe non-syndromic sporadic intellectual disability: an exome sequencing study. Lancet 2012;380:1674-82

117 Hamdan FF, Srour M, Capo-Chichi JM, Daoud H, Nassif C, Patry L, Massicotte C, Ambalavanan A, Spiegelman D, Diallo O, Henrion E, Dionne-Laporte A, Fougerat A, Pshezhetsky AV, Venkateswaran S, Rouleau GA, Michaud JL. De novo mutations in moderate or severe intellectual disability. PLoS Genet 2014;10:e1004772.

118 Hoischen A, van Bon BW, Gilissen C, Arts P, van LB, Steehouwer M, de Vries $P$ de RR, Wieskamp N, Mortier G, Devriendt K, Amorim MZ, Revencu N, Kidd A, Barbosa M, Turner A, Smith J, Oley C, Henderson A, Hayes IM, Thompson EM, Brunner HG, de Vries BB, Veltman JA. De novo mutations of SETBP1 cause Schinzel-Giedion syndrome. Nat Genet 2010;42:483-5.

119 Wiszniewski W, Hunter JV, Hanchard NA, Willer JR, Shaw C, Tian Q, Illner A, Wang $X$, Cheung SW, Patel A, Campbell IM, Gelowani V, Hixson P, Ester AR, Azamian MS, Potocki L, Zapata G, Hernandez PP, Ramocki MB, Santos-Cortez RL, Wang G, York MK, Justice MJ, Chu ZD, Bader PI, Omo-Griffith L, Madduri NS, Scharer G, Crawford HP, Yanatatsaneejit P, Eifert A, Kerr J, Bacino CA, Franklin AI, Goin-Kochel RP, Simpson G, Immken L, Haque ME, Stosic M, Williams MD, Morgan TM, Pruthi S, Omary R, Boyadjiev SA, Win KK, Thida A, Hurles M, Hibberd ML, Khor CC, Van Vinh Chau N, Gallagher TE, Mutirangura A Stankiewicz P, Beaudet AL, Maletic-Savatic M, Rosenfeld JA, Shaffer LG, Davis EE, Belmont JW, Dunstan S, Simmons CP, Bonnen PE, Leal SM, Katsanis N, Lupski JR, Lalani SR. TM4SF20 ancestral deletion and susceptibility to a pediatric disorder of early language delay and cerebral white matter hyperintensities. Am J Hum Genet 2013;93:197-210

120 Saul RA, Tarleton JC. FMR1-related disorders. In: Pagon RA, Adam MP, Ardinger HH, Wallace SE, Amemiya A, Bean LJH, Bird TD, Fong C-T, Smith RJH, Stephens K, eds. GeneReviews ${ }^{\circledR}$. Seattle, WA: University of Washington, 1993.

121 Sterling A, Abbeduto L. Language development in school-age girls with fragile $X$ syndrome. J Intellect Disabil Res 2012;56:974-83.

122 Berry GT. Classic galactosemia and clinical variant galactosemia. In: Pagon RA, Adam MP, Ardinger HH, Wallace SE, Amemiya A, Bean LJH, Bird TD, Fong C-T, Smith RJH, Stephens K, eds. GeneReviews ${ }^{\circledR}$. Seattle, WA: University of Washington, 1993

123 Waggoner DD, Buist NR, Donnell GN. Long-term prognosis in galactosaemia: results of a survey of 350 cases. J Inherit Metab Dis 1990;13:802-18.

124 Schweitzer-Krantz S. Early diagnosis of inherited metabolic disorders towards improving outcome: the controversial issue of galactosaemia. Eur J Pediatr 2003;162(Suppl 1):S50-3.

125 Schadewaldt P, Hoffmann B, Hammen HW, Kamp G, Schweitzer-Krantz S, Wendel $U$. Longitudinal assessment of intellectual achievement in patients with classical galactosemia. Pediatrics 2010;125:e374-81.

126 Hoffmann B, Wendel U, Schweitzer-Krantz S. Cross-sectional analysis of speech and cognitive performance in 32 patients with classic galactosemia. J Inherit Metab Dis 2011;34:421-7.

127 Dabell MP, Rosenfeld JA, Bader P, Escobar LF, El-Khechen D, Vallee SE, Dinulos MB, Curry C, Fisher J, Tervo R, Hannibal MC, Siefkas K, Wyatt PR, Hughes L,
Smith R, Ellingwood S, Lacassie Y, Stroud T, Farrell SA, Sanchez-Lara PA, Randolph LM, Niyazov D, Stevens CA, Schoonveld C, Skidmore D, MacKay S, Miles JH, Moodley M, Huillet A, Neill NJ, Ellison JW, Ballif BC, Shaffer LG. Investigation of NRXN1 deletions: clinical and molecular characterization. Am J Med Genet $A$ 2013;161A:717-31.

128 Ching MS, Shen Y, Tan WH, Jeste SS, Morrow EM, Chen X, Mukaddes NM, Yoo SY, Hanson E, Hundley R, Austin C, Becker RE, Berry GT, Driscoll K, Engle EC, Friedman S, Gusella JF, Hisama FM, Irons MB, Lafiosca T, LeClair E, Miller DT, Neessen M, Picker JD, Rappaport L, Rooney CM, Sarco DP, Stoler JM, Walsh CA, Wolff RR, Zhang T, Nasir RH, Wu BL, Children's Hospital Boston Genotype Phenotype Study G. Deletions of NRXN1 (neurexin-1) predispose to a wide spectrum of developmental disorders. Am J Med Genet B NeuroPsychiatr Genet 2010;153B:937-47.

129 Schaaf CP, Boone PM, Sampath S, Williams C, Bader PI, Mueller JM, Shchelochkov OA, Brown CW, Crawford HP, Phalen JA, Tartaglia NR, Evans P, Campbell WM,

Tsai AC, Parsley L, Grayson SW, Scheuerle A, Luzzi CD, Thomas SK, Eng PA, Kang SH, Patel A, Stankiewicz P, Cheung SW. Phenotypic spectrum and genotype-phenotype correlations of NRXN1 exon deletions. Eur J Hum Genet 2012;20:1240-7.

130 Wisniowiecka-Kowalnik B, Nesteruk M, Peters SU, Xia Z, Cooper ML, Savage S, Amato RS, Bader P, Browning MF, Haun CL, Duda AW, III, Cheung SW, Stankiewicz P. Intragenic rearrangements in NRXN1 in three families with autism spectrum disorder, developmental delay, and speech delay. Am J Med Genet B NeuroPsychiatr Genet 2010;153B:983-93.

131 Carvill GL, Regan BM, Yendle SC, O’Roak BJ, Lozovaya N, Bruneau N, Burnashev N, Khan A, Cook J, Geraghty E, Sadleir LG, Turner SJ, Tsai MH, Webster R, Ouvrier R, Damiano JA, Berkovic SF, Shendure J, Hildebrand MS, Szepetowski P, Scheffer IE, Mefford HC. GRIN2A mutations cause epilepsy-aphasia spectrum disorders. Nat Genet 2013;45:1073-6.

132 Lesca G, Rudolf G, Bruneau N, Lozovaya N, Labalme A, Boutry-Kryza N, Salmi M, Tsintsadze T, Addis L, Motte J, Wright S, Tsintsadze V, Michel A, Doummar D, Lascelles $K$, Strug L, Waters $P$, de Bellescize J, Vrielynck $P$, de Saint Martin A, Ville D, Ryvlin P, Arzimanoglou A, Hirsch E, Vincent A, Pal D, Burnashev N, Sanlaville D, Szepetowski P. GRIN2A mutations in acquired epileptic aphasia and related childhood focal epilepsies and encephalopathies with speech and language dysfunction. Nat Genet 2013;45:1061-6.

133 Turner SJ, Mayes AK, Verhoeven A, Mandelstam SA, Morgan AT, Scheffer IE. GRIN2A: an aptly named gene for speech dysfunction. Neurology 2015;84:586-93.

134 Bojesen A, Juul S, Gravholt CH. Prenatal and postnatal prevalence of Klinefelter syndrome: a national registry study. J Clin Endocrinol Metab 2003;88:622-6.

135 Herlihy AS, Halliday JL, Cock ML, McLachlan RI. The prevalence and diagnosis rates of Klinefelter syndrome: an Australian comparison. Med J Aust 2011;194:24-8.

136 Abramsky L, Chapple J. 47,XXY (Klinefelter syndrome) and 47,XYY: estimated rates of and indication for postnatal diagnosis with implications for prenatal counselling. Prenat Diagn 1997;17:363-8.

137 Nielsen J, Wohlert M. Sex chromosome abnormalities found among 34,910 newborn children: results from a 13-year incidence study in Arhus, Denmark. Birth Defects Orig Artic Ser 1990;26:209-23.

138 Lanfranco F, Kamischke A, Zitzmann M, Nieschlag E. Klinefelter's syndrome. Lancet 2004;364:273-83.

139 Alarcon M, Abrahams BS, Stone JL, Duvall JA, Perederiy JV, Bomar JM, Sebat J, Wigler M, Martin CL, Ledbetter DH, Nelson SF, Cantor RM, Geschwind DH. Linkage, association, and gene-expression analyses identify CNTNAP2 as an autism-susceptibility gene. Am J Hum Genet 2008;82:150-9.

140 Poot M, Beyer V, Schwaab I, Damatova N, Van't Slot R, Prothero J, Holder SE, Haaf T. Disruption of CNTNAP2 and additional structural genome changes in a boy with speech delay and autism spectrum disorder. Neurogenetics 2010;11:81-9.

141 Worthey EA, Raca G, Laffin JJ, Wilk BM, Harris JM, Jakielski KJ, Dimmock DP, Strand EA, Shriberg LD. Whole-exome sequencing supports genetic heterogeneity in childhood apraxia of speech. J Neurodev Disord 2013;5:29.

142 Roll P, Rudolf G, Pereira S, Royer B, Scheffer IE, Massacrier A, Valenti MP, Roeckel-Trevisiol N, Jamali S, Beclin C, Seegmuller C, Metz-Lutz MN, Lemainque A, Delepine M, Caloustian C, de Saint Martin A, Bruneau N, Depetris D, Mattei MG, Flori E, Robaglia-Schlupp A, Levy N, Neubauer BA, Ravid R, Marescaux C, Berkovic SF, Hirsch E, Lathrop M, Cau P, Szepetowski P. SRPX2 mutations in disorders of language cortex and cognition. Hum Mol Genet 2006;15:1195-207.

143 Cope N, Harold D, Hill G, Moskvina V, Stevenson J, Holmans P, Owen MJ, O'Donovan MC, Williams J. Strong evidence that KIAA0319 on chromosome $6 p$ is a susceptibility gene for developmental dyslexia. Am J Hum Genet 2005;76:581-91.

144 Dennis MY, Paracchini S, Scerri TS, Prokunina-Olsson L, Knight JC, Wade-Martins $R$, Coggill $P$, Beck $S$, Green ED, Monaco AP. A common variant associated with dyslexia reduces expression of the KIAA0319 gene. PLoS Genet 2009;5:e1000436.

145 Osborne LR, Mervis CB. Rearrangements of the Williams-Beuren syndrome locus: molecular basis and implications for speech and language development. Expert Rev Mol Med 2007;9:1-16. 